Florida International University FIU Digital Commons

FIU Electronic Theses and Dissertations

University Graduate School

7-19-2004

\title{
Navigating the past, envisioning the future : Octavia Butler's heroines
}

Dixie-Ann Belle

Florida International University

DOI: $10.25148 /$ etd.FI14050486

Follow this and additional works at: https://digitalcommons.fiu.edu/etd

Part of the English Language and Literature Commons

\section{Recommended Citation}

Belle, Dixie-Ann, "Navigating the past, envisioning the future : Octavia Butler's heroines" (2004). FIU Electronic Theses and Dissertations. 1484.

https://digitalcommons.fiu.edu/etd/1484

This work is brought to you for free and open access by the University Graduate School at FIU Digital Commons. It has been accepted for inclusion in FIU Electronic Theses and Dissertations by an authorized administrator of FIU Digital Commons. For more information, please contact dcc@fiu.edu. 
FLORIDA INTERNATIONAL UNIVERSITY

Miami, Florida

NAVIGATING THE PAST, ENVISIONING THE FUTURE:

OCTAVIA BUTLER'S HEROINES

A thesis submitted in partial fulfillment of the

requirements for the degree of

MASTER OF ARTS

in

ENGLISH LITERATURE

by

Dixie-Ann Belle

2004 
To: Dean R. Bruce Dunlap

College of Arts and Sciences

This thesis, written by Dixie-Ann Belle, and entitled Navigating the Past, Envisioning the Future: Octavia Butler's Heroines, having been approved in respect to style and intellectual content, is referred to you for judgment.

We have read this thesis and recommend that it be approved.

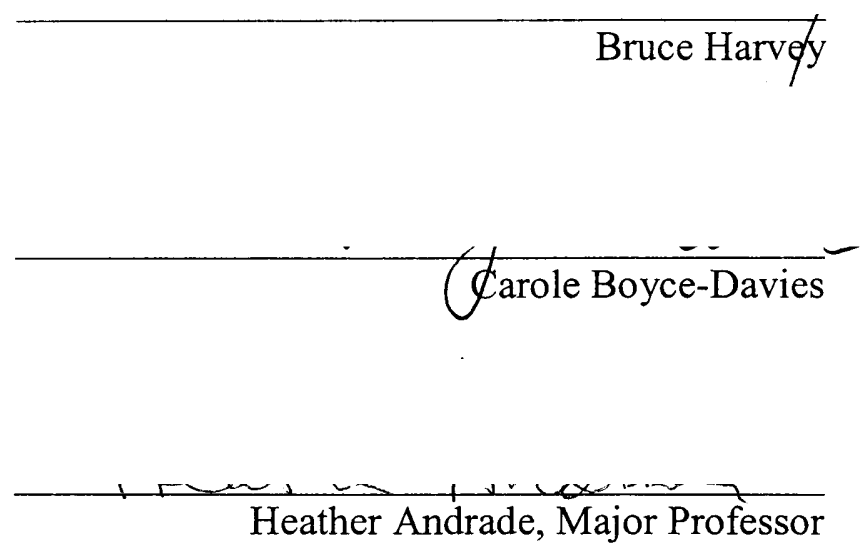

Date of Defense: July 19, 2004

The thesis of Dixie-Ann Belle is approved.

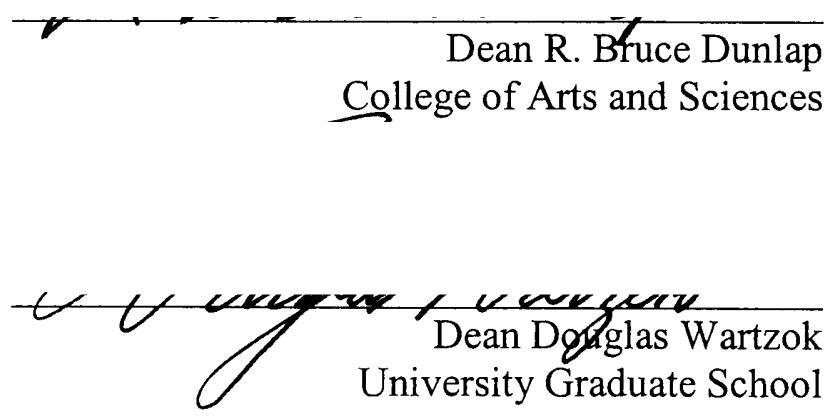

Florida International University, 2004 


\section{DEDICATION}

To Mom, Dad, Jr. and Shari and everyone at home for always having faith in me. 


\section{ACKNOWLEDGMENTS}

I would like to thank Dr. Kate Capshaw Smith for introducing me to the work of Octavia Butler and fueling my enthusiasm for my topic.

I would also like to thank my committee members for their interest in my work and for their valuable contributions which helped me refine my work. I am particularly grateful to Dr. Heather Andrade for her expansive knowledge of my topic, to Dr. Bruce Harvey for being there when I really needed him, and to Dr. Carole Boyce-Davies for giving me her time and patience. 


\begin{abstract}
OF THE THESIS
NAVIGATING THE PAST, ENVISIONING THE FUTURE:
\end{abstract}

OCTAVIA BUTLER'S HEROINES

by

Dixie-Ann Belle

Florida International University, 2004

Miami, Florida

Professor Heather Andrade, Major Professor

In this thesis, I examined three novels by African American science fiction novelist Octavia Butler: Kindred (1979), Parable of the Sower (1994), Parable of the Talents (1998) and Dawn (1987). I analyzed Butler's belief that society has become too firmly attached to old customs and belief systems, initiating destructive, self-defeating cycles in our history. She looks to African American females to take up leadership roles and exact radical change to ensure society's continued survival as well as progress, acceptance and autonomy within our communities. I also established Butler's significant contributions to the African American literary canon as she examines the history of African Americans and speculates on their necessary roles of shaping the future of society. 


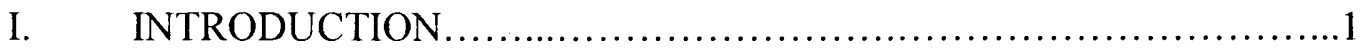

II. CONJURING THE GHOSTS OF THE PAST: REMEMBERING HISTORY IN OCTAVIA BUTLER'S “KINDRED”.....................9

III. DESTINY IN THE STARS: CHANGING THE PATH OF SOCIETY IN OCTAVIA BUTLER'S “PARABLE” NOVEL 49

IV. "OUR CHILDREN WILL BE BETTER THAN EITHER OF US": OPPRESSION, MISCEGENATION AND MEDIATORS IN OCTAVIA BUTLER'S "DAWN"'................................... 72

V. CONCLUSION ....................................................

BIBLIOGRAPHY ........................................................... 


\section{Introduction}

An obsession, according to my old Random House dictionary, is the "domination of one's thoughts or feelings by a persistent idea, image, desire, etc." Obsession can be a useful tool if it's a positive obsession. Using it is like aiming carefully in archery. (Bloodchild 129)

Sometime around the late 1950's, Octavia Estelle Butler took steps towards initiating her life's obsession when she walked into her first bookstore. The public library had already been a source of her fascination with books from the age of six; she bought her first two books in that bookstore at the age of ten. One was a book on horses; the other was a book which "described stars, planets, asteroids, moons and comets" (Bloodchild 126). She quickly became fascinated with writing down the stories which she had been telling herself for years. Despite the many rejections and discouragements she received, she aimed her pen stubbornly at her goal, honing her strength and skill with her reading and her fertile imagination. At the age of 23 , she finally struck her target when she published her first novel.

Nowadays Butler is a well known and popular figure in the science fiction genre and has carved herself a niche in the African American canon as well. She has won every major award in science fiction and has a dedicated following whom she describes as "feminists, blacks, and science fiction readers, with some New Age people as well. There are mainstream readers, too, who don't fit into any of those categories, who read me just because they enjoy my work" (Fry 476).

In his article, "Why Blacks Should Read (and Write) Science Fiction", Charles Saunders establishes her as a "giant" in her field, confirming her position in a genre he 
believes has been unfortunately neglected by black people because of the stereotypes rampant in early science fiction novels. Saunders affirms the necessity for African Americans to make inroads in the genre, noting that science fiction serves as "the mythology of our technological culture" (404). He adds, "We need to contribute to our culture's overall mythology as well, and provide alternatives to the stereotypes that continue to plague us within the mythology" (404). Saunders rightly pinpoints Butler's oeuvre as a sample of what an African American can do to change the genre significantly. Her black characters staunchly oppose stereotypical representations, regularly taking the spotlight in her work. In addition, her speculative landscapes freshly address issues of race which have been largely ignored in this genre for many years.

Many academics and critics recognize Butler's substantial contributions. An Internet search of syllabi of universities across America reveal that many of her novels, particularly Kindred (1979), Dawn (1987) and Parable of the Sower (1994), are requisite elements in examinations of feminist literature (particularly black feminism) and examinations of African American history and culture. In addition, Butler has also inspired other black females to make contributions to the genre. For example, in recent years Caribbean born writer Nalo Hopkinson has been recognized for her science fiction novels inspired by Caribbean culture and featuring black heroines. As Saunders has noted, there is still a very small number of black writers contributing to this genre, but the increase in the number of African Americans who read and write science fiction can be attributed to Butler's influence.

Butler herself does not seem inclined to retire from her position as the leading black writer in the genre. Her obsession to write has apparently not abated, but within her 
work, she has nurtured a new obsession. Sandra Y. Govan writes that "Difference, adaptability, change, and survival" are the "thematic threads" (84) which tightly link Butler's books a together. She is not the only female writer in the African American canon who portrays these themes, but she is very unique in approaching her work from the perspective of science fiction. While writers like Toni Morrison and Alice Walker look to present day and past society to comment on issues like race, feminism and power struggles, by looking forward as well as looking back, Butler is able to add the valuable dimension of the future to the African American canon, raising her questions on the future of not only African Americans but of all races in society.

Although the situations she creates are thought provoking, Butler's narratives are fiercely driven by the complex, realistic characters she creates. In her Introduction to Mythic Black Fiction: the Transformation of History (1986), Jane Campbell observes, "Idealism pervades black historical fiction" (ix). According to Campbell, black writers often create unbelievably heroic characters whose value rests in their creators' idealistic representations. In her novels however, Butler chooses to defy this pattern. Instead she creates characters who show human weaknesses, and as she tells us, heroes who are often not very pleasant (Butler qtd. Mixon). Her protagonists are usually black women locked in a struggle to adapt and stay alive in the midst of harsh and oppressive environments. Many of these women find themselves as leaders and mediators in their communities. These women are often forced to strike a balance between their communities and the forces bent on oppressing them. In their struggle to appease both sides, these women are rewarded alternately with acceptance and disdain. 
In her review of Octavia E. Butler's Dawn and Adulthood Rites, Adele Newson identifies this "double jeopardy" stating, "Entrapped in a society with different values (the least of which does not embrace her blackness), with the understanding that, no matter how she might want to assimilate, she won't be able to because of her color, she tries to accommodate both her people and her captors" (391). Newson sees this role as a type of go-between as "self-imposed", and it is true. Butler's heroines may feel compelled to take on roles of leadership, but they sometimes have the option to renounce their roles. However resigning as leaders in their communities would often mean giving up freedom, autonomy and the perpetuation of the community. Butler believes that this "self-imposed" role of black women is a necessary one. They must be the teachers, the leaders, the "crossroads" to help society along the path to change and a chance at survival. Even though as black women, they may be both "revered" and "despised" for their actions (Newson 393), Butler feels that they must take up these roles despite the dangers and abuse they may face.

These heroines are a necessary component if society is to make progress and outgrow its self destructive tendencies. Butler envisions a grim future for communities which continue to embrace destructive traits like intolerance and an abhorrence of change. The desire for complete autonomy in the face of oppressive forces often acts as the driving force behind the actions of her protagonists. Butler often reveals that this dream of independence is often unattainable. However despite the efforts of oppressive forces which seek to suppress their agency, the characters continue to claim and insist upon their right to choose their own futures. 
In Butler's oeuvre, one of the main weapons in the struggle for freedom is temporary submission. To all outward appearances, Butler's heroines may appear to accept the will of the oppressor, but this temporal submission is merely a survival tactic. These characters are not passive by any means. On the contrary, as Arnold Rampersad relevantly mentions in his article "DuBois's The Souls of Black Folk", "the slave's natural reaction to slavery was not passivity - which was learned later - but revolt" (114). Although he is describing slavery, Rampersad's argument pertains to Butler's characterizations. Butler's heroines never learn complete passivity. However, they do learn to use the appearance of passivity to protect themselves from persecution until the time comes to revolt. Sometimes they even make moral and physical sacrifices to ensure that they can stay alive. In other words, they make the best of their oppressive conditions whether they have been mysteriously transported to the past, or dwell in the postapocalyptic world of the future. Butler feels that these adaptable behaviors are universal and are still a vital element of surviving in the society we have created.

Critics have identified this potent resilience as a powerful essence in Butler's heroines. For instance, Sandra Y. Govan invokes the term "adaptability", and Ruth Salvaggio marvels at one heroine's "amazing capacity to compromise" (80). Butler's message then is clearly "adapt or die". Characters who remain inflexible to change cannot achieve freedom. This form of resistance can be traced to traditional responses to oppression depicted in $19^{\text {th }}$. century African American slave narratives. The enslaved often had to "put on a mask" of submission to guard their thoughts and plans for freedom until their hopes could be fulfilled. The power to choose a future path becomes an essential component in the enslaved life and the same is true in Butler's characterizations. 
Butler's characters also embody the pervasive theme of community common in the African American canon. Butler's characters may be powerful individuals, but they often act for the benefit of family and community. Besides, a sense of communal responsibility, Butler's characters support their community knowing that it is its members who must ensure long-term survival. They know that a well cultivated community will keep its members safe. They also know that through education, members of the community and its children can learn ideas, beliefs and goals to pass on to others. Therefore these ideas will live on. In return for giving others the freedom to shape themselves, the characters' treasured beliefs live on in the collective memory.

This need for survival and resilience in Butler's world is augmented by the bleak landscapes she creates. Idealism and hope are not Butler's main themes. Her "imaginary" scenarios are fueled with harshness and reality. Like many science fiction writers, her writing finds its foundation in the present. A careful student of politics, Butler uses the current path of society to predict the future, and her visions are often bleak. Butler's writing has distinct dystopian elements. She believes that "imperfect humans" are incapable of creating a "perfect" society. Some critics disagree with this assertion, pinpointing distinctly utopian ideas in some of Butler's works, yet her pessimism is unmistakable. Butler believes in change for society, but she is mindful that the change will be a painful process, and the results will be radical although not necessarily better. She affirms that society must be ready for these changes, that we must change with these rhythms or our chance at survival will be lost.

My study will examine three of Butler's novels for her assertions on the intolerance, conservatism and hierarchical tendencies which delineate contemporary 
society. Butler believes that society is executing a downward spiral which can lead to a world of extreme intolerance and stasis. She affirms that the fate of society lies on community leaders, particularly black women, who must guide community members to a more positive outlook of acceptance, diversity and liberalism. I will examine how Butler explores her predictions in the versatile, speculative science fiction landscape. I will also examine Butler's contribution to the African American literary canon.

In the first chapter Conjuring the Ghosts of the Past: Remembering History in Octavia Butler's Kindred, I focus on Butler's neo-slave narrative, Kindred (1979). In this novel of time travel, Butler uses the experiences of a woman on a slave plantation to detail the hardships of slave life and its implications on the slaves. In this chapter, I examine Butler's concern for African Americans who are becoming increasingly distanced from their past, and I argue that Butler uses her narrative to make the reader confront similar issues of fragmentation to overcome what Anne Anlin Cheng calls "racial melancholy".

The second chapter, Destiny in the Stars: Changing the Path of Society in Octavia Butler's Parable Novels, turns our attention to Butler's post-apocalyptic narratives, Parable of the Sower (1994) and Parable of the Talents (1998) which detail Butler's predictions for the future of society if we continue replaying the same selfdestructive cycles of intolerance, stagnant, inflexible belief systems and classicism. In this chapter, I discuss Butler's focus on the importance of adapting to change, and her vision of finding healing in technological advancement, in "shaping change" and in society finding "somewhere else" to start over and alter our destinies. 
In the final chapter, "Our Children Will Be Better Than Either of Us": Oppression, Miscegenation and Mediators in Octavia Butler's "Dawn", I examine Dawn (1987) the first book in Butler's Xenogenesis series. I examine the problems Butler foresees if human society were pushed into the cycle of radical change. In this novel, human society is "saved" by an alien race and made to change themselves against their will to cure society of its destructive habits. While Butler believes that such change is necessary, she predicts dangers and complexities in the process.

Through science fiction, Butler is able to speculate on human history and its implications on the present and the future. Her oeuvre highlights the necessity of change in the structure of our society, but she is well aware of the resistance radical change will receive particularly if it is initiated by African American woman as she suggests.

However, Butler believes that efforts to make changes must be made despite resistance from oppressors. She also focuses particularly on how race relations and hierarchical behavior can complicate the progress of society. As long as human beings remain imperfect, even our solutions will be tainted with these imperfections.

The task of her many black heroines is to survive and adapt as power struggles take place. They must also act as guides to a society which seems intent on initiating its own destruction. When the opportunity arises she has her heroines rise up in the face of oppression and manipulate the system to save their communities. This is the attitude Butler hopes to infuse into the African American community. The end result is to take definitive control of the future of society and the community and create a world where diversity is embraced and hierarchy has less influence on human behavior and societal structure. 


\section{Conjuring the Ghosts of the Past:}

\section{Remembering History in Octavia Butler's Kindred}

Something harder and stronger...clamped down on my arm-painlessly at first-melting into it, meshing with it... The wall of my living room. I was back home-in my own house, in my own time... But I was still caught somehow...my flesh had become part of the wall...It was the exact spot Rufus's fingers had grasped. I pulled my arm toward me, pulled hard. And suddenly, there was an avalanche of pain...And I screamed and screamed. (Kindred 261)

It is with this final terrifying scene that Octavia Butler's novel Kindred (1979) comes full circle. After several enigmatic trips into the $19^{\text {th }}$. century antebellum South, Butler's heroine Edana (Dana) Franklin struggles to free herself from the grip of the past and literally loses her arm in the process. This final violent act cements Butler's insistence that we can never fully escape the consequences of history.

A $20^{\text {th }}$ century black woman, Dana is fantastically transported into the antebellum American south. Through Dana, Butler is able to depict enslaved life through the eyes of a modern day woman, a black woman struggling to strike a balance in her life in both the past and the present. In the present, Dana has a chance of achieving this balance despite the issues which arise because of her interracial marriage. In the world of the enslaved plantation, she struggles to strike a balance between her association with blacks and whites and often fails because of the oppressive culture of the past which conditions the whites of the time to see the blacks of the plantation as objects or animals incapable of reason or emotion, undeserving of respect or equality. 
Butler's portrayal of Dana's experiences poignantly illustrate slave life and the struggle for survival which characterized each day of a slave's existence, but it also draws the modern day reader closer to the text. For example, a modern reader might read and be moved by a traditional $19^{\text {th }}$. century slave narrative, but because the reader has not experienced the slave's life, it is easy to feel detached and distanced from the issues in the text. Butler also suggests that modern day depictions of slavery encourage us to cushion our understanding of that institution; often we regard it in refined and romanticized terms which allow us to deny the terrible effects of slavery and its impact on both the past and present. As a consequence, it is necessary then for the text to instill the reader with the importance of reflecting on the past and to recognize its import on us all. Although Dana is a product of these present day feelings, she does not have the luxury of distancing herself from this painful history because she is dramatically living the history. Consequently, Butler invites the reader to identify closely with Dana and her experiences in the past.

However, one cannot escape the idea that history will naturally fade in our minds (though hopefully it will never disappear completely) because we cannot experience it first hand like Dana. It is inevitable that we will get a watered down version of the experience no matter how good the narrative is, whether it is Butler's narrative or any other author of neo slave works because we are never meant to fully regain the past, merely to be haunted by it.

Works like Kindred show that even a "watered down version" can help modern day readers to establish a connection with the past. Dana's experiences help readers to be transported by not only re-creating the plantation environment, but by using a $20^{\text {th }}$. 
century heroine who might think, feel and act similarly to $20^{\text {th }}$ century readers. Modern readers are exposed to ideas which force them to move beyond their comfort zones. Like the slaves before them, this knowledge might bring great bitterness and pain to contemporary readers as they are forced to face their denial of the past, but the freedom to think beyond the normal boundaries of everyday existence is acquired. Butler's works always assert that mental freedom is a vital part of living. Without mental freedom, life is not complete.

This sense of being haunted by the past however cannot be easily dismissed. It creates an emotional and poignant effect on contemporary society. Butler contends that the pain of racism cannot ever be completely forgotten or denied. In her book $\underline{\text { The }}$ Melancholy of Race (2000), Anne Anlin Cheng dubs this effort to subdue such anguish as "racial melancholia", a condition all races experience as they try to forget the pain of racism and paradoxically try to deny the pain exists at all. Toni Cade Bambara also recognizes the phenomenon noting, "In this society, forgetfulness is a virtue, amnesia is a virtue...we carry this habit, this outlook, into our daily lives. This is extremely dangerous" (351). Butler also recognizes this danger and presents the implications of such self defeating denial in Dana's adventures. As she struggles to create a stable family life for the slaves of the plantation in the past, Dana is forced to confront the pain ridden past of black people. In perusing Butler's narrative of pain and separation in enslaved life, the reader is starkly reminded of the part our ancestors played in the plantation's world of oppression and degradation. Like Dana, the reader is made to encounter a past that is being slowly and recklessly forgotten. 
Butler firmly situates Dana as a modern day woman by beginning and ending the text at Dana's modern home in the Los Angeles of 1976. Dana is inexplicably dragged into $19^{\text {th }}$ century Maryland. There she meets her direct ancestors. One of them is Rufus, a young white man to whom she is inextricably connected. Whenever Rufus' life is in danger, Dana is dragged into the past to save his life. She realizes the importance of her journeys because if Rufus does not live to father a child, her entire family line is threatened. During her time in the plantation, Dana plays the part of a slave to Rufus' family. She shares an understanding with the young man because she has saved his life so many times: Rufus is often reluctant to treat her harshly because he knows that Dana could easily have left him to die many times, and he feels an unwilling obligation towards her that transcends the social proscriptions of race and station.

Dana's position immediately puts her in a precarious position between the antagonistic groups of blacks and whites on the plantation. To the slaves of the plantation, Dana's closeness to Rufus is fawning and suspicious. Her different manners and clothes seem to target her as a white sympathizer, their pet, an enemy to her own people. When she finds herself alone with some of the slaves of the plantation, one slave, Nigel, suspiciously interrogates her:

Why you try to talk like white folks.' 'I don't,' I said surprised. 'I mean, this is really the way I talk.' 'More like white folks than some white folks'...'You'll get into trouble'...'Marse Tom already don't like you. You talk too educated and you come from a free state (Kindred 74) 
Nigel's statements accurately pinpoint Dana's position. As a black woman with her character and education, she is suspicious to her own people; to the whites of the plantation, she is a dangerous component of a dangerous race.

Dana must continually struggle to survive in the midst of the two groups, attempting to appease both sides and never quite succeeding. Like many black women she faces what Adele Newson calls "a double jeopardy" (391). Newson writes, "Entrapped in a society with different values... with the understanding that, no matter how she might assimilate, she won't be able to because of her color, she tries to accommodate both her people and her captors" (391). Butler understands this conflict. Her heroines face this "double jeopardy" (391) in many of her novels.

Ostensibly Dana must act as an intermediary to stay alive, to try to fit in her new and hazardous environment. Yet her precarious position actually places Dana in more threatening situations. As we shall see later, in her attempts to conciliate the various plantation groups, she is more likely to turn their anger and bitterness on herself. Yet Butler has her continue to struggle and attempt to make changes where she can. Despite the danger and disadvantages, Butler feels that Dana as a black woman is a necessary intermediary. Her efforts to make changes do make a difference though Dana questions whether the results are good or bad. For example, she saves Rufus's life again and again, knowing that if he dies, the plantation families will be divided up and sold. Yet, she feels torn when she watches him abuse slaves like Alice, and she wonders if her interference is doing any real good. The important condition for Butler is that Dana and all black women must stay in the middle, influencing the world. The black woman's influence is necessary to effect change or society risks stagnation. 
Not surprisingly Dana suffers a great deal because of her perilous position. She suffers not only because she is a slave but because she must convince her other ancestor, a slave called Alice, to give in to the aggressive advances of Rufus to ensure the birth of the child who will literally "give birth" to Dana's bloodline.

As she waits for this event, Dana often finds herself in danger. At these moments, she is drawn back into the present though the time difference between past and present is not relative. In other words, in the narrative enactment, a few days in the present mean several years in the antebellum South. Dana's security in the present and her relationship with her white husband Kevin are severely threatened because of the uncertainty of the timing of her sudden visits. They are forced to be separated several times, full of fear of what will become of each other during the separation. The powerful effects alter their lives drastically. Her time in the past exposes Dana to severe physical and mental abuse from which she cannot fully escape until her ancestor is born and Rufus is dead. Even Kevin is left with deep emotional scars when he is accidentally transported into the past with Dana when he grabs onto her just as she is vanishing. She is his only means of moving back and forth through time, and when Dana is wisked back into the present again when he is not near her, she leaves him behind. Because of the time difference, Dana does not see him again until several years have passed in the antebellum South, and in the meantime Kevin must confront the devastating abuses of slave owners on slaves.

The time difference between the present and the past also allows Dana to have an accelerated vision of the progress of the plantation. Over the years, she watches Rufus grow and take over the management of the estate. He becomes hardened, a product of his time period. As Dana watches, Rufus is able finally to possess Alice and to have two 
children, one of whom is Hagar, Dana's direct ancestor. Alice never fully accepts her role as concubine and continuously plans ways to escape and to gain freedom for her children. Dana notices that Alice loses some of the fire she had in her younger years, but she holds on to hope for her children. Alice frightens Rufus with her unrelenting desire for autonomy, so he sends the children away and tells Alice he has sold them in an attempt to break her completely to his will. However, for Alice, Rufus has crossed a boundary which is unforgivable, and she fights back by hanging herself and putting herself forever out of Rufus' reach. Without Alice, Rufus turns to Dana for comfort and attempts to rape her, but this is an action that Dana refuses to tolerate. She stabs him to death and ends her journeys into the past forever as she is transported home once again but leaves her arm behind.

In many ways, the experiences of both Dana and Alice bring the life of an enslaved person into the consciousness of the modern day reader. The reader is reminded of the resilience and determination which characterized the lives of those enslaved on an antebellum plantation. As Dana lives the life of a slave, Butler also reminds the reader that it is impossible to try to escape from painful memories of the past and that forgetting the impact of the past can be perilous as well. In other words, because Dana has lost touch with her past, she must live through these experiences to create the bond again, she faces the pain of racial melancholy and fragmentation from a lack of connection to her ancestry. For her it brings physical and emotional pain. This same pain parallels the racial melancholy which is felt by all Americans. Dana's experiences act as a means to bring the notion of this melancholy out into the open. Instead of denying the existence of 
a painful past, the reader is reminded of his or her own danger of becoming fragmented and broken by disconnecting with the past.

As a type of neo-slave narrative, Kindred paints a picture of slavery for the modern reader which is far less restrained than the writings of black autobiographers of the past. In his article, "Beloved: A Womanist Neo-Slave Narrative; or Multivocal Remembrances of Things Past", Bernard W. Bell argues that Toni Morrison gives a more introspective version of the typical slave narrative: "because of the silences in the slave narratives due to authorial compromises to white audiences and to self masking from a painful past, Morrison sees her role as a writer as bearing witness to 'the interior life of people who didn't write [their history] (which doesn't mean that they didn't have it) and to fill[ing] in the blanks that the slave narrative left" (97). In other words, while conventional slave narratives could not relate certain aspects of slavery because of limitations imposed on the genre by society and the narrator's emotional guardedness with regard to the past, authors like Morrison are distanced enough from the events of the past to detail information which was hitherto shielded. Butler also uses Kindred to tell a story of what Morrison terms, those "unspeakable things unspoken" (368) that characterized the oppressive conditions under which African Americans had to live and the lengths to which they were made to survive and attain freedom. In Morrison's Beloved, for example this freedom means "to get to a place where you could love anything you chose - not to need permission for desire" (10). Her characters merely wish for the chance to shape their futures. In a similar vein to the themes of Beloved, the themes explored in Kindred teach us about the quest for freedom on slave plantations and underline the necessary resilience of plantation slaves. 
With Beloved, Kindred shares a decided preoccupation with the idea of the past literally coming back to haunt you. Even the horrifying legacy of the notorious Middle Passage is invoked in Butler's narrative. In his Introduction (1998) to the novel, Robert Crossley identifies the parallel between Dana's fictional journey and the historical terrors of the Middle Passage. He writes, "In her experience of being kidnapped in time and space, Dana recapitulates the dreadful, disorienting, involuntary voyage of her ancestors" (xi). Even though Dana's experiences in the past do not literally include the Middle Passage, she cannot even escape from that particular memory. As if to reinforce the lesson, she must make the journey through to the past and back many times, each time experiencing unpleasant sensations of nausea and disorientation:

I began to feel dizzy, nauseated. The room seemed to blur and darken around me. I stayed on my feet for a moment holding on to a bookcase and wondering what was wrong, then finally, I collapsed to my knees...I raised my head and discovered that I could not focus on him. (Kindred 13)

Dana's discomfort gives her a minor taste of the suffering experienced by men and women forced to endure the Middle Passage. Her suffering is also a physical manifestation of her racial melancholy. In her transitory process towards confronting the past, her body seems to reject the unwanted and unanticipated journey.

Anne Anlin Cheng observes that part of the experience of racial melancholy is a sense of resentment against the object which has been lost (8). Using Freud's writings on melancholy as a springboard for her ideas, Cheng explains that the melancholic digests the grief generated by the loss. Feelings of "guilt, rage and punishment" then erupt (8); therefore ironically "the melancholic would have to make sure the object never returns, 
for such a return would surely jeopardize the cannibalistic project that, one might note, is a form of possession more intimate than any material relationship" (9). Therefore, caught up in the comfort zone of denial, the melancholic (Dana) does not wish to revisit the pain of the past, preferring instead to wallow in the denial and guilt of the present. However the forces in Kindred are determined to make sure that Dana confronts her denial. The short journey to the past is a small discomfort compared to the abuse Dana endures during her sojourns at the plantation. Through Dana's experiences, Butler illustrates the torturous feelings which accompany an exploration of the African American past, but she makes it clear that this exploration is an essential one to prevent the past from being lost to us completely. The process of untangling the complicated web of pain associated with racial melancholy is as urgent as the force which pulls Dana from her simpler modern day life.

From the moment the enslaved Africans' feet touched the shores of the New World, they began a ruthless initiation into the regulations of plantation culture. This school of instruction was merciless and unbending. Slaves learned the rules quickly or risked death. From almost the moment she first arrives in the past, Dana must quickly make similar adjustments. For example, on one of her early trips, she is introduced to the harshness of punishments dealt out to slaves. She is hidden nearby when a slave is brutally beaten and she listens, "he began to moan - low gut wrenching sounds torn from him against his will." She continues,

Finally he began to scream. I could literally smell his sweat, hear every ragged breath, every cry, every cut of the whip. I could see his body jerking, convulsing, 
straining against the rope as his screaming went on and on... Why didn't they stop! (Kindred 36)

Here Butler reinforces the accounts given in many narratives written about the institution of slavery, but she presents them through the lens of a twentieth century perspective.

Dana, like many of us today, had never witnessed a slave being beaten. She had undoubtedly read accounts of such punishments, but she could not understand the pain and the immediacy of the suffering unless she witnessed it herself. In this narrative instance, Dana reveals:

I had seen people beaten on television and in the movies. I had seen the too-red substitute streaked across their backs and heard their well-rehearsed screams. But I hadn't lain nearby and smelled their sweat or heard them pleading and praying, shamed before their families and themselves. I was probably less prepared for the reality than the child crying not far from me. (Kindred 36)

It is impossible for the reader not to think introspectively at this point and wonder if we in our time can truly understand the extent of the suffering experienced by the dehumanized victims of the slave trade. We are after all products of the same media images as is Dana. It seems unlikely that we are any more prepared than is she.

The extent of the physical abuse inflicted on the slaves of the South is reinforced with Dana on each trip she makes. During each return to the present, she is suffering from severe injuries; most of these wounds are due to the violence inherent in the everyday slave existence. Dana is subjected to callous physical abuse from the white people around her, but it is hardly less than what other slave women have had to face. Once an overseer strikes her across the breasts; at another time, she is kicked in the face and loses 
teeth. Twice she is whipped brutally until she feels she will die. Like many slave women, Dana bears the marks of her hard life: "My back was cut up pretty badly too from what I could feel. I had seen old photographs of the backs of people who had been slaves. I could remember the scars, thick and ugly" (Kindred 113). Painful and horrifying as her whippings are, they are hardly less agonizing than the punishments detailed in slave narratives.

For instance in The History of Mary Prince $(1831)^{1}$, Mary is brutally beaten by her mistress then by her master for allegedly breaking a jug. Slaves were typically subjected to such punishments which were as sadistic as they were inhumane. It is not inconceivable that Prince's scars were similar to Dana's.

At the end of the narrative of Kindred, Dana experiences a final mutilation when her arm is amputated, literally left in the past as she is drawn into the future for the last time. Dana, and presumably the reader, is taught a critical lesson about losing connection to the past. Dana's amputated arm symbolizes the consequences of forgetting. The loss of her arm is traumatic and painful, and it will remain a terrible memory that she cannot escape. Like many amputees, Dana will often feel as if the arm is still there while remaining excruciatingly aware of its absence. In the same way, the history of Dana's ancestors cannot be erased; its effects will always be felt. However despite the drastic effects of facing racial melancholy, Butler ends Kindred with the message that the injuries incurred from this struggle to reconnect with the past, it is a necessary step

\footnotetext{
${ }^{1}$ Prince's narrative states that her master struck her several times with his hand promising to hit her a hundred times the following day. Prince laments, "He kept his word...He tied me up upon a ladder, and gave me a hundred lashes, and master Benjy stood by to count them for him... after resting, he beat me again and again, until he was quite wearied...I was so sore from the flogging, that I scarcely cared whether I lived or died" (The History of Mary Prince 264).
} 
toward healing, to becoming whole. Toni Cade Bambara emphasizes the importance of finding this connectedness noting, "To be whole - politically, psychically, spiritually, culturally, intellectually, aesthetically, physically, and economically whole - is of profound significance. There is a responsibility to self and to history that is developed once you are "whole"' (348). Dana at last recognizes this responsibility and her mind is not on her loss but on her chance to find peace as the narrative closes with a conversation between herself and Kevin, "If we told anyone else about this, anyone at all, they wouldn't think we were so sane" (Kindred 264). Having confronted the inherited fragmentation which distanced her from her ancestry and her self, Dana ironically is broken in body but closer to emotional health and well-being.

Butler also uses Dana's experiences to depict the threat to the unity of the blacks on the plantations. Family bonds were discouraged by plantation owners. Slave owners did not want slaves to have any chance of forming alliances against them. Efforts were made to discourage strong family feeling. Dana has a taste of this family separation because she experiences separation from her husband on a regular basis, and her movement through time literally tears them away from each other. However, unlike the members of many slave families, Dana has the consolation of hoping that they will be reunited. She is better off than many slaves who often never saw friends and families again when they were sold and who had little chance of finding them again. Dana's situation emphasizes the advantages of modern day African American life where blacks have more opportunities to form strong family bonds and create a support system to help them and guide them. 
Slaves were deprived of this type of comfort. Harriet Jacob's narrative is an excellent example of the impact of this type of forced separation ${ }^{2}$. Most of Jacobs' hardships are generated by the danger of her two children being sold. Slave narratives often emphasized the effects of such loss on both parents and children. Many slave narratives begin with accounts relating the authors' lack of knowledge about their parents. Female narrators, like Harriet Jacobs, poignantly depict the devastating and dehumanizing results of having children torn from their mothers and sold into slavery. In Kindred, Sarah the plantation cook embodies this motherly agony when she tells Dana of her own loss.

The expression in her eyes had gone from sadness - she seemed almost ready to cry - to anger. Quiet, almost frightening anger. Her husband dead, three children sold, the fourth defective and her having to thank God for the defect. She had reason for more than anger. How amazing that Weylin had sold her children and still kept her to cook his meals. How amazing that he was still alive. (Kindred 76) Sarah's children were sold for money needed to buy furniture. Later on Rufus sells a young black man who he believes is paying too much attention to Dana. For the whites of the plantation, the sale of black people is like simply exchanging one inanimate object for another. We are reminded of the standard practice in slave culture of reducing black bodies to objects to be traded for profit. These acts serve as a further emphasis of the

\footnotetext{
2 In one of the most heartbreaking scenes in her life story, Jacobs describes the typical slave woman's New Year's Day when all slave children who have been sold are taken away from their families. She writes, "To the slave mother New Year's day comes laden with peculiar sorrows. She sits on her cold cabin floor, watching the children who may be torn from her the next morning; and often does she wish that she and they might die before the day dawns... she has a mother's instinct, and is capable of feeling a mother's agonies" (457).
} 
dehumanizing aspect of slavery; not only are slaves reduced to a less than human condition, but white people are conditioned to see human beings as chattel. The plantation culture chips away at the humanity of all individuals involved.

Butler's narrative reveals how slave owners created disunity among slaves by encouraging them to turn against each other. When Dana tries to escape, she is betrayed by a slave who goes to the master. Consumed by jealousy because of Dana's "favored" position, she goes to Tom Weylin knowing that she will be rewarded for her betrayal. One of the reasons slave rebellions were so rare was that slaves were often encouraged to betray each other in return for special favors. The manufactured division between favored slaves and the rest of the population or the one between field slaves and house slaves helped breed jealousies and suspicion. However, slave narratives and novels like Kindred show that despite everything, there is an inviolable bond among African Americans. The noted $19^{\text {th }}$. century slave narrator and abolitionist, Frederick Douglass recalls the sense of brotherhood he shared with several other of his fellow slaves, reaffirmed when they are foiled in an escape attempt ${ }^{3}$. Douglass shows that honor could exist among the slaves although pro slavery advocates sought to depict otherwise.

In like manner, Butler is fully aware that slaves were capable of deception and betrayal, she does not ignore the fact that strong communal feeling could and did exist. Dana's fellow slave women band together to punish the traitor and make sure she does not complain. Betrayal would not be tolerated. In addition, for most of the novel, Dana is often helped by her fellow slaves. They warn her if they think she may be in danger

\footnotetext{
DDouglass writes, "We were resolved to succeed or fail together, after the calamity had befallen us as much as before... Our greatest concern was about separation. We dreaded that more than any thing this side of death" (Narrative of the Life of Frederick Douglass 409) (1845).
} 
and try to help her understand the rules of her harsh environment. Butler continues the legacy of past slave narrators by counteracting the stereotype of brutally acquisitive African Americans, with emphasizing their truer inherent nature of community bonding. Even in unnurturing environments, community feeling could not be completely dampened or stamped out.

Another facet of plantation culture which was rampant and yet oft-times rendered invisible in the public sphere was the threat of rape which haunted black women. Nineteenth century slave narratives could not graphically address issues of rape. To avoid offending the "gentility" of Northern readers, the content of their narrative was frequently censored. Therefore one of the most horrific aspects of the slave existence was often given little textual treatment. In many cases, it is unlikely that the narrators would have been eager to relive painful memories. Yet even when rape is discussed in censorious language, the $19^{\text {th }}$. century slave narratives still reveal painful and affective representations of sexual abuse.

Authors of neo-slave narratives have much greater license to examine these acts of violation. Although Butler's depictions are not overly graphic, she does portray images which are much more vivid than could have been discussed in a conventional slave narrative. Even in Harriet Jacobs' novel Incidents in the Life of a Slave Girl (1862) in which the narrative action is fiercely driven by the fear of rape, the suggestive violence depicted in Kindred would not have been published. In one scene, a white patroller coming to rape a slave woman finds Dana instead and attacks her with unmistakable intent. Dana is not his target, but for the patroller it makes little difference. "I guess you'll do as well as your sister...I came back for her, but you're just like her" (Kindred 
42). Butler effectively presents how widespread and common was rape and the threat of rape. The white patroller's nonchalance with Dana proves that one black woman is interchangeable for another, an attitude which reinforces the stereotype of black women as objects. As Dana is objectified in the narrative, we are reminded of modern day depictions of black women. The almost daily threat of rape is no longer as pervasive, but the objectification of black women continues though in the widespread depiction of them as playthings and objects of denigration in modern media. Interestingly enough this perspective on black women was pervasive in the South and accepted. Nowadays this objectification is still acceded under the guise of it being a routine element of pop culture like subjugated women in rap videos. The irony of this continued denigration is brought home to the reader as we are forced to imagine Dana assaulted and subordinated on the ground.

Butler's narrative is a testimony to the fear of rape which is inherent in all women. At the same time, she proves that $20^{\text {th }}$ century women have advantages and empowerment which protects them from the danger of rape far more than their ancestors ever could. In the midst of her encounters with exploitation and physical and mental abuse, rape is the only violation Dana feels that she cannot tolerate. When she is brutally attacked by the white patroller, she at first hesitates to strike out at him. "I raised my hands to his face... In that instant, I knew I could stop him, cripple him in this primitive age, destroy him...But I couldn't do it. The thought sickened me, froze my hands where they were. I had to do it! But I couldn't..." (Kindred 42).

Clearly, Dana's $20^{\text {th }}$. century conditioning and aversion to violence prevents her from acting. The denial inherent in racial melancholy rises to the fore here. Dana's mind 
chooses to refute her immediate danger in favor of remaining in her comfort zone. However when it becomes clear that the patroller really means to rape her, Dana is prepared to react at last. She strikes her attacker down with a tree limb. Dana finds that she cannot tolerate the implications of the deliberate blindness of racial melancholy. Her aversion to oppression and objectification move her to overcome her conditioning. When shortly afterwards, Kevin presents her with a switchblade to carry with her on her journey and asks if she will use it, Dana replies firmly, "Yes. Before last night, I might not have been sure, but now, yes" (Kindred 47). Already Dana is beginning to overcome some of the handicaps of the blindness which she has always lived with. Her final victory comes after she grimly endures Rufus' abuse for sometime without trying to hurt him. When he makes an effort to rape her, she strikes him despite the bond she shares with him. The moment of attack is also Dana's attempt to strike out at the racial injury which has been inflicted on so many black women. She refuses to allow her fragmentation to overcome her and degrade her as it has done for others.

Dana's empowerment is also particularly evident in her choice of mate. Butler emphasizes Dana's ability to choose the man she wants to be with. In her essay "Not Enough of the Past", Angelyn Mitchell calls Dana "an empowered agent in her contemporary environment" and observes that "Her twentieth century environment does not suppress, commodify or abuse Dana's sexuality" (46). Dana's husband Kevin is white, and their relationship is based on mutual affection. However Butler utilizes the couple's interactions for more than a token nod at interracial relationships. Despite the disapproval of relatives, there are few real obstacles to stop Dana and her husband Kevin from being together. Critics note the benefits of the couple's bond. Mitchell highlights 
"the mutuality and compatibility of their nascent sexual and emotional relationship" (46) and observes that when Dana has intercourse with Kevin, "sexual intercourse is an act of liberation, a way of confirming one's reality and grounding one's self in that reality" (47).

In antebellum Maryland, with luck, Dana is able to maintain her freedom to choose a mate, and this helps dispel the persistent stereotype of "hypersexuality" which has been attributed to black women for years. When Dana has been separated from her husband for some time, she refuses the advances from a slave on the plantation, determined to stay true to her husband. Ironically, she actively experiences the stereotype when she is caught sleeping in her own husband's room. The plantation people know nothing of their marriage, so they view the relationship with the usual mixture of disapproval and secrecy. The mistress of the house slaps Dana across the face when she discovers that she has been sleeping in Kevin's room, screaming, "You filthy black whore... This is a Christian house" (Kindred 93). Yet when Tom Weylin sees Dana leaving Kevin's room: "He almost smiled - came as near smiling as I'd ever seen. And he winked" (Kindred 97). Dana feels ironically ashamed of this situation as many slave women must have felt when this hypocritical relationship was imposed upon them. Even when her relationship with Kevin could be considered "legitimate, she cannot escape from the conflicted life of a slave woman.

However, Dana's determination to choose the man she prefers gives her empowerment. Mitchell points out that like her predecessor, Harriet Jacobs in Incidents in the Life of a Slave Girl, Dana acts as a contrast to the stereotype of the promiscuous black woman promulgated by racist propaganda. 
Dana's empowerment is also evident in her "re-education" of her husband.

Kevin can only visit the past by traveling with Dana. Because he does not want to be left behind the next time Dana time travels, he must stay with her, forcing him to see and experience the antebellum South in the same environment where Dana is endangered and restricted. Because he cannot go off to an area where he is not as exposed to the trials of black people, Kevin is forced to absorb some of his wife's experiences through her perspective. In her article, "De-Essentializing Interracial Representations; Black and White Border-Crossings in Spike Lee's Jungle Fever and Octavia Butler's Kindred" Diana R. Paulin observes, "Despite his power as a white man, he cannot return without Dana's help, which indicates the reciprocal nature of their relationship and suggests that his decision to take part in this experience is part of a cooperative effort" (187). Kevin is forced to forego some elements of white dominance because of his dependence on Dana. Part of her empowerment comes from impelling him to understand the contours of the painful past characterized by violence, sexual abuse and exploitation, a past to which they both must lay claim.

Kevin's relationship with his wife also makes a powerful statement on the relations between white men and black women in the $19^{\text {th }}$ century. Rufus and Alice's relationship acts as a distorted reflection of the modern couple's marriage. While Dana and Kevin's relationship is based on some mutual respect and support, Rufus and Alice's relations are overshadowed by the debilitating effects of the power between the slave and her master. Rufus feels driven to coerce and abuse Alice because this is the conditioning he has received all his life, and as a consequence Alice hates him and the culture Rufus represents. They experience no mutual respect for each other. Rufus is unable to find a 
balance between his desire and love for Alice and his firm belief that she is inferior to him. Their relationship brings them little satisfaction and provides stress, guilt and fear rather than support and comfort. Since Dana's sexual agency is an exception to the slave culture, Alice serves as the example of what many black women actually had to face. Angelyn Mitchell erroneously suggests that Dana's freedom to choose her mate proves that black women "could make choices even in their deterministic world and that their own personal codes of morality were valid and intact" (50). Butler's narrative does not imply that black women had complete freedom to choose their mates. On the contrary, she highlights how difficult it was to uphold this desire for freedom in the midst of the oppressive plantation culture.

Even Dana, who is relatively safe from such advances, can understand Alice's lack of choice. Acting as the unwilling mediator between Alice and Rufus, she herself outlines Alice's agonizing options which are not real options at all: "You can go to him as he orders, you can refuse, be whipped, and then have him take you by force; or you can run away again" (Kindred 167). Alice has already run away once and been nearly killed for it. Her only choice is to go to Rufus willingly (which she does) and harbor her plans to have her children freed.

Despite this lack of choice which was common in plantation culture, Butler and Jacobs do manage to show how strongly slave women felt about the violations which they faced, and the reader is left in no doubt that the slave woman was often forced to act against her wishes. Harriet Jacobs expresses the slave woman's longing for freedom of sexual agency when she observes, "There is something akin to freedom in having a lover who has no control over you except that which he gains by kindness and attachment" 
(501). In the $20^{\text {th }}$. century, Dana enjoys the freedom to choose a compatible, compassionate lover, while the typical black woman of the antebellum South could often only hope for the opportunity to have this freedom of choice.

The contrast between Dana and the slave women on the slave plantation in terms of their sexual agency emphasizes the difference between the situations for women today compared to the ancestors who lived upon the plantations. Looking back on the particular trials of the black woman awakens a sense of kinship in both black readers and women of all colors. It fulfills the goal of the slave narrative by illustrating the hardships of oppression and sexual exploitation the black slave woman had to face.

Part of the reason for Dana's sexual agency in the 19th. century can be attributed to her $20^{\text {th }}$. century literacy. Dana's experiences with slave education strongly reinforce the value placed on education in slave narratives. Narratives by both Frederick Douglass and Harriet Jacobs stress what education meant to the future of slaves. A literate slave could write passes that would fool authority figures when they were far from home. He or she could read maps and find out information on a good route for escape. They could read their Bible and make interpretations that encouraged freedom, and opposed oppressive teachings, and they could read abolitionist literature and pass on the information they gathered to the illiterate. Frederick Douglass describes his plan to write passes for several of his friends. In her work, Harriet Jacobs describes the ignorance of slaves who could not read and outlines her efforts in instructing those willing to learn.

Slave masters were often very careful to keep their servants ignorant fearing that knowledge would make them "unfit" for work. Ironically their fears were justified. In the Narrative of the Life of Frederick Douglass (1845), Douglass reveals how reading 
gave him a self awareness of how oppressive his life as a slave really was. His master severely chastised Douglass' mistress for trying to teach the young slave how to read: "A nigger should know nothing but to obey his master - to do as he is told to do. Learning would spoil the best nigger...if you would teach that nigger... how to read there would be no keeping him, it would forever unfit him to be a slave...it would do him no good, but a great deal of harm. It would make him discontented and unhappy" (364). Amazingly the Master's bigoted words are correct. Douglass teaches himself how to read and discovers abolitionist literature. The realization that dawns on him fills him with disgust, "The more I read, the more I was led to abhor and detest my enslavers" (367). He adds, "As I read and contemplated the subject, behold! That very discontentment which Master Hugh had predicted would follow my learning to read had already come, to torment and sting my soul to unutterable anguish. As I writhed under it, I would at times feel that learning to read had been a curse rather than a blessing" (370). Douglass proves here that in the warped culture of slavery, even the benefits of education can be converted to a burden. Albeit it is a burden which eventually secures his freedom.

What Douglass and other slaves experienced in such situations was the pain that accompanied the journey to mental freedom. They too were trying to overcome a type of racial injury of their own. Plantation culture tried to ensure that slaves had little knowledge or ideas beyond their everyday existence. They were chained mentally to this limited way of thinking until literacy broke them free. Through the acquisition of literacy, they began to nurture an existence outside of what they had always known garnering a type of mental freedom which could bring bitterness, but this mental freedom could also encourage a fierce desire for complete autonomy from the slave culture. 
In keeping with this thematic link between literacy and freedom characterized in the 19th. century, the advantages and disadvantages of literacy are very evident in Kindred. Everyone on the plantation knows the implications of Dana's knowledge. Tom Weylin fears that Dana will be "putting freedom ideas" (Kindred 74) in slaves' heads. "Like we so dumb we need some stranger to make us think about freedom" (Kindred 74) one slave observes with scorn, but Weylin's fears have some justification. The slaves do not need Dana to fuel longings for a better life, but her abilities give her the means to teach them to escape. Dana agrees to educate the slaves who ask her to teach them knowing the benefits to them. By doing this, she begins to undermine the slave culture. Any slaves who could read not only became "unfit" for slavery, but they became better equipped for escaping. Dana was effectively giving them the tools to steal themselves away from their masters and disrupt the workings of the plantation structure.

However Butler also spends a great deal of time reflecting on the dangers of Dana's education to herself and others. Her literacy is treated with suspicion by Tom Weylin, and Rufus uses it to exploit Dana, making her help him with managing the plantation. Dana has little choice when it comes to disobeying Rufus, but she puts effort into her work to appease him and to try to have some control over the workings of the plantation. Her role as mediator is apparent here as she works both for the white master and her fellow slaves, but to Rufus she is merely a tool to be used. The treatment of the slave as an object becomes especially apparent here. To the whites of the narrative, Dana's abilities are meant to be exploited until she is no longer useful to them. Dana's twentieth century education gives her more knowledge than an antebellum doctor, allowing her to help save the lives of both Alice and Rufus. However while knowledge 
brings respect and prestige to the white doctor, it only leaves Dana open to exploitation and danger. She is not revered or respected for her talents. Since she is under the thumb of these white men, they begin maneuvering her in order to take advantage of her as much as possible. For example, when Rufus is so ill Dana thinks she may not be able to save him, Tom Weylin warns her,

You're something different. I don't know what - witch, devil, I don't care.

Whatever you are, you just about brought a girl back to life when you came here last, and she wasn't even the one you came to help...You're not natural! But you can feel pain - and you can die. Remember that and do your job. Take care of your master. (Kindred 206)

The conditioning of the whites will not allow them to view anything pertaining to the blacks as a blessing. Weylin, steeped in his own prejudices, can only see Dana as an evil entity who he must threaten and abuse.

The reader is strongly impressed with the idea of how completely plantation culture engendered tension and enmity between blacks and whites. When Dana is caught teaching young slaves to read, she gets the worst punishment, she has yet received in the past. "I treated you good," Tom Weylin admonishes her, "and you pay me back by stealing from me! Stealing my book! Reading!" (Kindred 107). Dana is then whipped for the first time in the antebellum South; until, she feels as if she is near death. Through Weylin's castigation, we are given a graphic depiction of the impact education could have on slave culture. Plantation owners such as Weylin had good reason to fear educated slaves who might try to escape from them and to feel as if something valuable was being stolen from them when slaves began to learn literacy to free themselves. The 
value of an education for the slave becomes vividly clear. Butler also emphasizes how the slave culture could link even education with torture and oppression, leaving the reader with a strong impression of how completely plantation culture was saturated with violence and cruelty.

Butler also uses Dana's knowledge to suggest that modern day education does us a disservice by softening us to hardships. Dana learns to regret her learning bitterly when she realizes that it does not stand her in good stead when she tries to escape from slavery. When she is brought back after a failed escape attempt, she is beaten and is filled with pained, bitter thoughts. She reflects on Alice and thinks,

We were both failures, she and I. We'd both run and been brought back, she in days, I in only hours. I probably knew more than she did about the general layout of the Eastern Shore. She knew only the area she'd been born and raise in and she couldn't read a map. I knew about towns and rivers miles away - and it hadn't done me a damned bit of good! What had Weylin said? That educated didn't mean smart...Nothing in my education or knowledge of the future had helped me to escape. Yet in a few years an illiterate runaway named Harriet Tubman would make nineteen trips into this country and lead three hundred fugitives to freedom. (Kindred 177)

Despite her "advanced knowledge", Dana is ignorant of the survival techniques which were common knowledge to her ancestors. She tries to survive in the weakened mental state of modern day racial melancholy and often fails. In Dana's failure, the reader is left with an impressive picture of the endurance and fortitude of "ignorant" slaves who were able to accomplish the impossible. The books Dana has read about slavery and the media 
she has seen have provided her with a softened form of the experience and rendered her ill-equipped to navigate her way through the treacherous realities of plantation culture. Although our contemporary lifestyle no longer requires us to be versed in survival techniques, Butler appreciates the endurance of our ancestors and asserts their resilient qualities so the reader may appreciate them as well.

However physical stamina was not the only beneficial qualities of the life of enslaved people. Mental freedom also fueled resistance for slaves, and one manifestation of this is clear in neo-slave narratives. Because of their limited ability to resist the oppression of plantation culture, slaves often learned to be duplicitous, to mask rebellious feelings. Outright defiance was often impossible, but resistance could still be manifested in less harmful ways from behind the mask of duplicity. One example of such a technique was compromise. For the slaves, this meant adapting to their environment and submitting to the oppressive acts of their white masters. It meant doing as they were told and putting on a face of submission. It meant giving up physical freedom, so many of the slaves did not go beyond the boundaries of the plantation without the permission of the master. Compromise could also mean giving up a certain amount of sexual freedom. But according to the narratives' purview, there was a deeper purpose to employing these conciliatory techniques: the slave was trying to survive in a harsh environment until the opportunity to escape manifested itself.

The type of compromise practiced by Dana and many of the slaves is not complete submission. The slaves of Kindred, like many slaves of African American autobiography, kept their mental freedom. Mental freedom is the one thing that was almost impossible for slave owners to control. For example, once Frederick Douglass 
began really reflecting on the issue of slavery, he became determined to gain his freedom and nothing deterred his resolve for long. He of course, "played the part of a slave", but in his mind he was completely free. In a similar way, Harriet Jacobs would not allow her opinions to be swayed by her master, and none of her hardships discouraged her from hiding from him for her own safety and for that of her children. This is why she was able to hide out in a garret only "nine feet long and seven wide" (567) for seven years.

In $\underline{\text { Kindred, }}$, no slave embodies the fawning, obsequious Negro stereotype which can be found in old movies. Butler's slaves put on a face of compliance, while barely hidden beneath this mask is a fierce, defiant soul waiting for the slightest provocation to break free. In one key moment, Tom Weylin's personal slave Nigel gives him a "look of disgust that would surely have angered him if he had seen it" (Kindred 65). In another instance, when Weylin gives Nigel's wife presents after she has a baby, Nigel complains bitterly to Dana, "Cause of Carrie and me, he's one nigger richer"" (Kindred 161). Dana notes however, “...before the Weylins, he was properly grateful” (Kindred 161). When Rufus visits one of their parties, the slaves praise him for his generosity to his face. When he leaves, Dana observes that "they made gross jokes about him behind his back" (Kindred 229). Even Sara, who Dana at first sees as a sort of "Mammy" figure too afraid to actively resist, violently curses the master and mistress who have caused her so much misery. Her behavior is a testament to the fierce desire for autonomy which characterized many slaves.

The noted African American anthropologist and writer, Zora Neale Hurston has noted that this ability to mask was a typical modality of black culture. She terms such 
acts "feather bed resistance". In her novel, Mules and Men (1935), she describes this propensity towards duality in the following way,

The Negro, in spite of his open-faced laughter, his seeming acquiescence, is particularly evasive. You see we are a polite people and we do not say to our questioner, 'Get out of here!' We smile and tell him or her something that satisfies the white person because, knowing so little about us, he doesn't know what he is missing... The Negro offers a resistance. That is, we let the probe enter, but it never comes out. It gets smothered under a lot of laugher and pleasantries. (4-5)

By practicing this type of resistance, the slave actually was playing to the white person's stereotype of the shallow, fawning slave who apparently harbored nothing beneath the surface except the basest desires. The philosophy here is that this mask left the slaves free to think and feel as they wished within themselves. Mental freedom was achieved with the sacrifice of putting on a face to prevent their oppressors from suspecting their true feelings. Nigel expresses a very similar idea to Dana, "Don't argue with white folks...Don't tell them 'no'. Don't let them see you mad. Just say 'yes sir'. Then go 'head and do what you want to do. Might have to take a whippin' for it later on, but if you want it bad enough, the whippin' won't matter much" (Kindred 96).

While most of the slaves exercise this clandestine defiance, only Alice openly defies Rufus Weylin at first; later on she learns to give in. Alice was born free and suffers great pain getting used to the idea of giving up her autonomy. She is nearly killed when she is mauled by dogs during an escape attempt. Later she goes to Rufus willingly. "She adjusted," Dana observes, "became a quieter more subdued person. She 
didn't kill, but she seemed to die a little" (Kindred 169). Butler shows that these terrible compromises come at the great cost of guilt and hopelessness. But she also shows that Alice has not stopped resisting. She continues to plan for her children's freedom.

Dana must compromise as well, though she is able to keep some of her freedoms. The average slave could not survive if he or she was always rebellious. Most of the slaves in the narrative have been born slaves except for Alice. All of them have known slave culture all their lives. Dana has never known it, so she must learn to adapt to an entire new world, a new time. She manages to learn to do this fairly quickly, playing the part of the obedient slave and dealing with $19^{\text {th }}$ century inconveniences. Dana herself marvels at her own adaptability.

Time passed. Kevin and I became more a part of the household, familiar, accepted, accepting. That disturbed me too when I thought about it. How easily we seemed to acclimatize...it seemed as though we should have had a harder time adjusting to this particular segment of history...for drop-ins from another century, I thought we had had a remarkably easy time. And I was perverse enough to be bothered by the ease. (Kindred 97)

Later Dana reasons that it is her twentieth century conditioning which makes her feel this way, but this ability to adapt to the environment is also a capability inherent in many of Butler's heroines. In her article "Octavia Butler and the Black Science-Fiction Heroine", Ruth Salvaggio notes that one of Butler's heroines has "an amazing capacity to compromise" $(80)$. It is this ability that helps Dana adjust. She realizes the danger of standing out. She must play by the rules of her new environment or risk losing her life. When she does not act the part of the submissive slave, she risks being whipped or 
abused. She too must offer "feather bed" resistance when she is faced by Tom Weylin, his wife and other whites. She conditions herself so she remembers not to look whites in the eye. She must not forget to say "yes sir" and "no sir" and to hide any defiance she may feel.

Dana's role as mediator becomes particularly apparent in her attitude toward the blacks and whites of the plantation. She goes further than playing the submissive slave because she is close to Rufus. Despite the prejudice he harbors, he is friendly to Dana. He protects her from the worst punishments and allows her to work in the house. Dana cultivates their connection from the beginning of their relationship to ensure that she stays alive. Later she works with him to try to alleviate some of the suffering of the slaves of the plantation. She saves Rufus' life repeatedly knowing that if he dies, the families on the plantation will be broken up and sold. Her hold on Rufus' life protects the slaves from an uncertain fate, but her situation also draws jealousy, hatred and suspicion from the slaves. The result is a sense of guilt and alienation.

Dana accepts her role as mediator, but she fully appreciates the pain and suffering associated with her difficult position. For example, she is filled with conflict as she tries to convince Alice to accept Rufus aware that she is betraying a fellow black woman to save her. She thinks, "I couldn't refuse to help the girl - help her avoid at least some pain. But she wouldn't think much of me for helping her this way. I didn't think much of myself" (Kindred 164). This painful conflict infects many of Dana's interactions with both blacks and whites on the Weylin plantation. Her situation reflects the life of many black women, struggling to make life better by appealing to opposing sides, yet she is 
despised and hated because of her necessary role. However without a doubt, her role is necessary to ensure the community endures.

Other forms of resistance surfaced when opportunities presented themselves. Sometimes slaves staged fierce and open revolts. Occasionally individuals or small groups were able to escape, but these instances were not common. Butler does not depict successful escapes or revolts. She presents a more normative picture of plantation life where slaves escaped and were brought back like Alice, or like Sarah, they feared escaping because they did not know where to go.

Only one slave in the narrative has the strength to overcome the boundaries of fear successfully. Because of her relationship with Rufus, Alice finds the means to hurt him by her actions. Few slaves had the emotional hold on their masters that Alice wields, and she is able to defy Rufus by taking her own life. Alice role in the narrative acts as a contrast to Dana. She is unwilling to try to appease the opposing forces in her life. She is constantly at odds with the blacks around her, with Rufus and not surprisingly with Dana. While Butler makes most of her heroines the crossroads between opposing sides, she creates in Alice an anomaly. She has a different purpose: to strike at the heart of the enemy.

While making Alice submissive and pliable to his will, Rufus unconsciously is giving her the weapons to injure him because of the inevitable bond that forms between them. Alice is able to flout his authority one last time. Dana foreshadows Alice's suicide when she cuts her wrists. When Rufus strikes her, Dana feels that he has broken an unspoken rule between them. She slices her wrists hoping the deadly act will bring on the fear of death necessary to "send her home". 
In many of her novels, as in Kindred, Butler uses suicide as a formidable tool of defiance. Angelyn Mitchell has noted this as well. She writes, "While Alice's suicide may be seen as an act of emotional weakness or an act of familial abnegation, it is not. Alice exercises her right to choose death - freedom of a different sort - over bondage" (54). For Butler, suicide is not an act of cowardice. It is an example of the powerless taking back power, seizing their chance to shape their future. In death, the slave has finally escaped and is completely beyond the reach of her master. Dana seizes her autonomy by finding a way to send herself home, but she hopes that she will not die. IN Butler's purview, the mediator advocates survival. She does not easily give in to the wish for death. However, Butler suggests that Alice displays still greater courage when she hangs herself without the hope of survival. She has decided not to accept the mediator role where she must fight to establish a balance in her community. However she makes another statement against oppression. It cannot indefinitely hold her against her will.

Throughout the narrative, Butler suggests that Alice's ability to resist is rapidly deteriorating. Alice experiences the danger of wearing the "mask" too long. The deception can begin to compromise the autonomy within the individual. The fiercest blow to Alice's autonomy occurs when she tries to escape with her husband. She is brought back, severely mangled and is close to death. Her husband is sold. Rufus buys her to prevent her from being sold down South, so she is no longer free even in the eyes of the law. All at once Alice is robbed of her autonomy and much of her strength. For some time, she cannot bring herself to try escaping again. When Rufus forces her to give in to him, he takes more steps in breaking down the autonomy she values. The birth of 
her children pleases her but also serves to chain her more firmly to her life on the plantation. Her children are ironically simultaneous symbols of her imprisonment and her desire for freedom. "'I don't mean to spend my life here watching my children grow up as slaves and maybe get sold" (Kindred 233) she tells Dana. "When I'm strong again after I have this baby, I'm going.' 'With the baby?' 'You don't think I'm going to leave it here, do you?...Get me a bottle of laudanum...I'll have the baby to keep quiet"” (Kindred 233).

Alice's desperation arises not only because of her desire for freedom, but because she fears she will learn to accept the life she is being forced to lead. "I got to go while I sill can," she tells Dana, "'before I turn into just what people call me"” (Kindred 235). Butler shows that Alice still harbors hope despite the obstacles which have been steadily placed in her path. Even when Alice begins to give up hope of ever escaping herself, she places her hopes firmly on her children. When they are taken from her, she decides to commit one final act of defiance to free herself once and for all. As Dana stares at the body, she notices, "She wore shoes that Rufus had had made specifically for her, not the rough heavy shoes or boots other slaves wore. It was as though she had dressed up and combed her hair and then..." (Kindred 248). Alice has tried to die with as much dignity as she can, and she has "thumbed her nose" at Rufus one more time by wearing the shoes he had placed on her as his concubine. Alice had hoped to give her children the chance to shape their own futures. When this option is taken from her, she performs this definitive act of revenge.

As already noted, the doomed, debasing relationship between Alice and Rufus stands in stark contrast to the nurturing, supportive one of Kevin and Dana. Alice and 
Rufus embody the painful, destructive elements of black and white relationships, but Butler uses the other couple to suggest that healing is possible with collaboration between both black and white people. Without a doubt, Kevin's presence in the past also emphasizes the importance of the need for both races to be aware of the history they share.

This visit to the past forces both Dana and Kevin to take stock of their relationship and of the vicious past of their ancestors. Diana A. Paulin reinforces this idea when she writes, "Dana and Kevin are forced to learn each other's history through lived experience and to accept the results of the interaction of their ancestors, which, in turn, helps them to understand the power dynamics informing their relationship in 1976" (179). The disparity between their histories is starkly evident from the moment they arrive in the past. Kevin is safe from persecution and is inclined to think of the experience as an adventure. After he and Dana have been together in the South for some time, he remarks, "This could be a great time to live in...I keep thinking what an experience it would be to stay in it - go West and watch the building of the country, see how much of the Old West mythology is true" (Kindred 97). Dana cannot understand his fascination with a time which holds no acceptance, no safety and no freedom for her and her people. She says bitterly, “"West...That's where they're doing it to the Indians instead of the blacks!' He looked at me strangely. He had been doing that a lot lately" (Kindred 97). Kevin's look highlights the disparity between the couple which their almost idyllic $20^{\text {th }}$. century marriage did not confront. Paulin continues by noting that, "The different levels of pain, suffering, recognition, and denial that Dana and Kevin experience reinforce the inequality of damage that each of them incurs" (188). She 
observes that Kevin comes out of the journeys to the past with a scar on his forehead while Dana loses teeth, incurs scars on her back and loses an arm (188). Butler graphically depicts the disproportion between the lives and histories of blacks and whites during antebellum slavery and shows the need for both groups to come to terms with this dissimilitude. Paulin observes, "It becomes evident that transformed thinking is a necessary step in working though the complexity of, in this case, black/white relations in order to redefine what is considered transgressive behavior" (180).

Kevin and Dana are forced to confront these differences, and despite the fact that he escapes extreme physical abuse, Kevin is made to see the past in a new light. Like Dana, he must confront his own denial of the sorrow of the past. Seeing Dana's danger and living in the past for several years exacts a dramatic change in him. During his separation from Dana, he travels as he had planned and is horrified by the cruelty he sees around him. When he and Dana return home, he says, "Everything is so soft here....It's good. Hell, I wouldn't go back to some of the pestholes I've lived in for pay" (192). Butler shows that Kevin has emotional scars as we watch him struggle to adjust to life again in the $20^{\text {th }}$. century. When he tries to write about his experiences, he finds that he cannot find the words. While at his typewriter, "He fumbled with that for a moment, remembered how to turn it on, then looked at the stack of blank paper beside it and turned it off again. Abruptly he brought his fist down hard on it" (Kindred 194). For a writer like Kevin, to be unable to express himself in his work is tragic and his trouble telegraphs the turmoil in his mind. It also suggests his emotional distance from the tragedies that happened. Even when confronted with the history, he cannot completely relate to the sorrow of black people. Like many whites in the past who have tried to articulate the 
horrors of slavery, he is unable to express the sorrow of blacks fully because their sorrow is not his. Kevin's limited experience with the horrors of slave culture render him speechless, a pale imitation of the years of sometimes enforced, sometimes involuntary silence of black people.

Besides this disparity between the sorrow of whites and blacks, Butler uses the whites of Kindred to emphasize the effect history has on white people as well as black ones. Their scars may not be as obvious, but clearly emotional scars are numerous. The distortion of white humanity is embodied in many slave narratives. Frederick Douglass outlines the transformation slavery brought upon some whites when he described how his white mistress, who formerly treats him with kindness and compassion, is drastically altered when she is warped by the power she has over her enslaved servant ${ }^{4}$. In a similar vein, in many of her novels, Butler explores the corruption that power over others can exact on human beings. Absolute power acts as an almost autonomous entity seizing and warping otherwise humane individuals beyond all reason, like Frederick Douglass' formerly kind mistress. Dana fears that Kevin will experience this same transformation, but he manages to avoid this danger though the antebellum South leaves a lasting effect on him. Butler illustrates that even the oppressive element of absolute power can be thwarted though the odds are great. For example, Kevin is able to resist the degradation of his humanity because he has had $20^{\text {th }}$. century conditioning. Despite all she can do, Dana cannot impede the effect of absolute power on Rufus because he has been

\footnotetext{
${ }^{4}$ Douglass expresses great distress in the alteration in the behavior of this women who at first had, "the kindest heart and finest feelings...she had been a good degree preserved from the blighting and dehumanizing effects of slavery... But alas! This kind heart had but a short time to remain. The fatal poison of irresponsible power was already in her hands, and soon commenced its infernal work" (Narrative of the Life of Frederick Douglass 363).
} 
conditioned by $19^{\text {th }}$. century culture. The fact that Kevin is able to resist its effects is a testimony to the fact that the effects of slavery, though far reaching, can be nullified.

At the close of the novel, it is up to the couple to decide if their varying experiences will divide them or force them to examine their racial differences together.

Diana R. Paulin notes,

Their wounds may help them to work together to recover and to rebuild their strength; or these different wounds may intensify the destructive power dynamics that perpetuate inequality and dominance, forcing Kevin and Dana to go their separate ways and fend for themselves...It is evident that the relationship between blacks and whites is mutually interactive; yet power and privilege continue to accompany white skin and the male gender. (189)

In other words, the pain of the histories of Dana and Kevin has the capability to pull their marriage apart or to give them a different foundation on which to build. Despite the fact that white male supremacy continues to dominate many facets of society, Kindred suggests that no progress can be made to healing unless the races work on a level of equality; it cannot happen for either group independently. Butler gives us hope that understanding will be generated between the races. Angelyn Mitchell writes, "Butler's libratory narrative teaches that both Black and White Americans must confront their shared past of racism, must acknowledge the pain and scars of their past, and must live together as kindred" (60). Paulin observes that Kindred ends with the assertion that Dana and Kevin have made the decision "to remain together as a more resilient and empowered couple" (189). Butler ends Kindred with a scene depicting Dana and Kevin in $20^{\text {th }}$. century Maryland researching the eventual fate of the residents of the Weylin plantation. 
The image of them working together to discover more about this history which once held them in its violent grasp suggests hope for a growth of understanding between blacks and whites everywhere.

In her reworking of the traditional slave narrative, Octavia Butler is able to step outside the genre like none of the original narratives could, impressing the severe consequences of ignoring the impact of history on the present upon the reader. We are left with the knowledge that the hardships and atrocities of slave culture cannot be ignored or completely exorcised. Anne Anlin Cheng affirms this philosophy when she writes, "it can be damaging to say how damaging racism has been. Yet it is surely equally harmful not to talk about this history of sorrow" (14). Butler's work performs the function of illustrating the importance of discussing this history. As a slave narrative it details events of the past through a black woman struggling to achieve balance in a fragmented society, and in addition, it manages to revisit the effect of this same culture

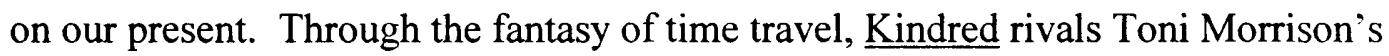
Beloved (1987) in bringing the past to us with startling clarity. Because history is memory, it cannot ever be fully recovered; works like Beloved and Kindred conjure up the ghosts of the past to allow our history to possess us and teach us the importance of remembering. Kindred therefore is a necessary step in the evolution of the slave narrative in the African American literary canon, the next logical path to take in the maturation of the genre. 


\section{Destiny in the Stars: Changing the Path of Society}

\section{in Octavia Butler's Parable Novels}

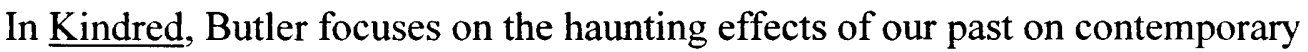
society, in her post apocalyptic novels, Parable of the Sower (1994) and Parable of the Talents (1998), she turns her mind to the potential disasters which may characterize the future of society.

In his article, “Post-Apocalyptic Hoping: Octavia Butler's Dystopian/Utopian Vision" Jim Miller explains that while many female science fiction writers like Ursula Le Guin and Marge Piercy create narratives of utopian futures, Octavia Butler focuses on the possible dystopian futures of our society and the way we must deal with these possibilities. Miller asserts:

Butler does not offer a full-blown utopian 'blueprint' in her work, but rather a post-apocalyptic hoping informed by the lessons of the past... Butler stares into the abyss of the dystopian future and reinvents the desire for a better world. In doing so she places herself firmly within a rich tradition of feminist utopian writing. (Miller 336)

While it is true that her works act to forecast the future of society if it continues along its current path, in her Parable novels, Butler reveals that healing for society is possible. Such salvation can be found in seeking control of the future instead of passively accepting change.

For example, the Parable protagonist Lauren Olamina lives her life hoping for a better world for her community and her family. She acts as a "cross roads" figure in this fantastic landscape, guiding people along an alternative route to a future which may have 
better possibilities with regard to survival, tolerance and autonomy. In her article, "Octavia Butler's Parable of the Sower" Lisbeth Gant-Britton concurs,

The daughter's [Lauren's] decidedly forward-looking vision contrasts with Toni Morrison's concept of 'rememory' in Beloved, in which discursive healing is seen almost exclusively as a backward-looking project to allow African American men and women to engage and re-envision what Morrison calls 'unspeakable things unspoken'. But in Parable of the Sower, we see a shift of that past-oriented temporality of 'rememory' forward. We then have a model which allows readers to conceptualize the future in a broader manner. Butler's model privileges proactive rather than reactive service. (283)

In other words, unlike many of her peers who highlight empowerment and healing by looking into the past, the Parable series suggests that strength can also be found in focusing on the future and adapting proactively to change. With the complexity that conventionally characterizes Butler's oeuvre, the texts foresee many obstacles thwarting change, not the least of which is society's tendency to repeat old customs and habits. This chapter analyzes Butler's belief that society is on a path to anarchy and degradation if radical change is not effected in our belief systems and our hierarchical structure. I examine how the novels outline a community which embraces change and tolerance in an attempt to thwart the danger of society's downfall.

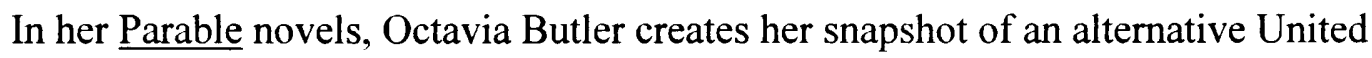
States. The narratives of her books are riddled with unsettling images of a future world which is uncannily possible. Parable of the Sower and its sequel Parable of the Talents respectively paint a picture of a disturbing world, characterized by poverty, oppression, 
and violence, which many Americans, many of them in the African American community, have begun to find all too familiar. We are introduced to this threatening environment at the beginning of Parable of the Sower as we find Lauren and her family living in a gated community in futuristic Los Angeles. Butler envisions a future of a world gone mad where the distance between the rich and the poor has increased exponentially. The rich are holed up in fortified mansions to protect themselves from the desperately poor who roam the streets. Life on the streets means almost certain death as people wander about in search of food and sustenance or range about in packs of drug crazed gangs. The community lives in fear that the horrors beyond their walls will encroach on their safety, and each group tries to fortify itself against "outside" dangers, ironically creating a prison for the families in their homes and in their own minds. Only Lauren and a few others seem to realize that many of the members of the community are embracing an ineffectual hope that having faith in the old status quo (which pushed them into their current ominous state) will eventually improve their lives. Only a few innovative individuals realize that change and adaptation is the only hope they have for survival, but Lauren's voice is not heard by those wishing to cling to the old ways. While Lauren's community remains huddled fearfully behind their meager defenses, the outer world breaks into the fragile walled compound with a violence disconcertingly reminiscent of real-life events. One night a gang of drug addicts drives a truck through the gate which had protected the neighborhood for all of Lauren's life. The "pyro" addicts (so called because of their tendency to light fires while high on drugs) attack because they believe that the community is part of the oppressive movement depriving them of basic necessities, of life and of their humanity. They cannot direct 
their anger at the richest members of society, so they only strike out at those who are accessible: communities like Lauren's which are struggling to supplement their own depleting resources. As Jim Miller writes, "The only problem with the movement is that they never reach the rich, focusing instead on those who have next to nothing rather than nothing at all" (350). Butler and Miller both echo the lament of many lower class African American communities where criminals, like starving animals trapped in the same cage, often prey on families and individuals within their neighborhoods, while privileged, and often white, neighborhoods are relatively untouched by their attacks.

It is impossible not to read the passage where Lauren describes the assault on her neighborhood without thinking of similar accounts of the horrors of looting in Los Angeles after the Rodney King trial which arose because of a similar sense of desperation, poverty and bitterness after years of police abuse and racism. ${ }^{5}$ The instance of the complete acquittal of the police officers who had brutalized King was minor when compared to the numbers of people in the past who have been beaten and sometimes killed by police officers who escaped punishment. The high profile case of Rodney King was all that was needed to ignite a conflagration which had been brewing for some time. In a similar way, years of pain, abuse and desperation had been building in the people who prowled around the walls of Lauren's neighborhood. The violence that erratically erupted was evidence of the smoldering emotions building among the desperately poor. The attack on the neighborhood is a small scale image of the Rodney

\footnotetext{
${ }^{5}$ On March 2 1991, a bystander videotaped three Los Angeles police officers brutally beating an African American man they had pulled over. The resulting footage of the violence dealt on Rodney King was widely aired on the media, and public opinion was strongly in favor of sentencing the officers. However, an all white jury acquitted the officers a year later, and the outrage that followed provoked the infamous Rodney King riots which rocked poor neighborhoods in South Central, Los Angeles for five days.
} 
King incident related violence, all the more volatile because of the amount of violence and rage contained in one small community.

Ironically the simmering emotions erupt into literal flames. Lauren writes, "when I escaped from the neighborhood, it was burning. The houses, the trees, the people:

Burning" (Sower 137). Images of burning businesses and homes in the South Central LA streets in 1992 come vividly to mind in comparison. Lauren's description also reflects the same hopelessness, waste and futility which characterized the destruction and the looting of the property of South Central store owners. She writes, "The ruins were still smoking, but men, women, and children were all over them, digging through them, picking fruit from the trees, stripping our dead, quarreling or fighting over new acquisitions, stashing things away in clothing and bundles... Who were these people?" (Sower 142) This description parallels the images which characterized media coverage during the Rodney King riots. Gripped by bitterness and a desire to right past wrongs, desperate individuals take advantage of the absence of oppressors and fall on anything which they can secure, nameless faces in a sea of destitution. Doubtless Butler had seen these images herself, and they were probably uppermost in her mind as she wrote the scenes in $\underline{\text { Sower. }}$

In addition, Lauren's journal details elaborate "fortress" homes where the wealthy live relatively untouched and protected by small private armies. This coincides with the real-life situation in Los Angeles where residents in the richer areas like the Baldwin Hills above South Central and South Carthay near Beverly Hills were not deeply affected by the violence of the riots. The situation is paralleled in almost every major city in the United States and many countries of the world. In many countries, the middle class are 
rapidly disappearing while the gap between rich and poor must be guarded to prevent desperate people from striking out in anger and frustration. For example, in a quote cited in a Time magazine article on the Rodney King riots, a caller at a radio station noted, "that residents in white neighborhoods were able to deploy private security forces to keep the rioters at bay" (28). The caller ended with the bitter, forlorn complaint, "Who can we call to get someone to protect our house?" (28).

Like the people of South Central, Lauren and her family have no one to come to their rescue when the mob rule takes over. While the people of Los Angeles had a tardy police force which eventually ended the worst of the looting, Butler creates a worst case scenario. After the neighborhood is destroyed, Lauren must flee out into the world beyond her community. Unlike the troubled inner cities of today, the world outside is worse than the walled communities. There are no havens to which to escape. As Lauren and her friends begin their trip through the Los Angeles of destitution, we cannot help but be uneasy that our society might be going in the same direction.

At the time of the publication of Parable of the Sower, Butler's narrative would have brought vivid memories to the minds of those who had experienced the riots only a year before. Now a decade later, the novel serves to remind readers of the past and turn their eyes with concern to the future. A native of Los Angeles and an avid student of political trends, Butler is not only looking back on history in $\underline{\text { Sower, }}$ but making eerie forecasts on future events. Few can contest that the volatile race relations which surrounded the Rodney King trials have not been diluted despite the fact that many years have passed. Despite steps taken to improve race relations in the United States, it can be argued that a considerable number of steps have been taken backwards. We are left with 
the fear that the number of safe havens for the majority of the lower classes will continue to diminish until we are like Lauren, fleeing from the horror of her destroyed community into a greater, hellish wilderness.

While some readers have suggested that Butler in this regard, has created a bleak, hopeless vision of the future in the Parable series, this attitude completely ignores the message of empowerment which Butler weaves throughout the novels. Long before her neighborhood is destroyed, Lauren begins drafting the preliminary ideas of her autonomy based philosophy which requires its followers to act rather than resort to passivity. She writes in her journal,

For whatever it's worth, here's what I believe... This is the right one, the true one.

This is the one I keep coming back to: God is Power -

Infinite,

Irresistible,

Inexorable,

Indifferent,

And yet, God is Pliable

Trickster,

Teacher,

Chaos,

Clay.

God exists to be shaped.

God is Change.

This is the literal truth. (Sower 22) 
From a very young age, Lauren begins to draw together the ideas of Earthseed which are born out of her disillusionment with the Baptist teachings of her father and her own inward musings. She questions the idea of a god who allows terrible things to happen to the people he has created. She distrusts the idea of leaving an individual's fate to a god when she has watched older people of her community wait for change and receive no benefits for their patience.

She decides instead that "God is change" (Sower 22) that everyone must expect change and be willing to work with the changes. For example, she is discouraged and irritated with the people of her neighborhood compound who stay hiding behind the community walls hoping that things will change for the better. She tries to preach preparedness to those around them and when she does not get any support, she prepares herself for the inevitable change which will shake up their lives. In her journal she writes, "I used to wait for the explosion, the big crash, the sudden chaos that would destroy the neighborhood... To begin Earthseed, I'll have to go outside" (Sower 110).

According to Lauren, the god of change can be manipulated and maneuvered when the time is right. It is important to know when to wait attentively and when to act decisively. Lisbeth Gant-Britton observes how different this attitude is from the more passive teachings of older members of the community: "What does it mean that her father's God now exists to be changed by people, rather than the other way around? Empowerment" (285). Lauren feels compelled to live according to this belief system and to pass on her teachings to others. It is not enough for her to have this vision; others must learn the lesson of adaptation. There is no question of whether she should take charge, but of how best her roles can be achieved. Although the situations the characters must 
face are indeed desolate, there is hope in the fact that Butler does not make her characters helpless in the midst of this desolation. Those that take control of their fates can have some hope.

Butler seems to share Lauren's compulsion to spread the lessons of adaptation and empowerment. These two themes are inextricably interwoven into many of her novels. For example in the follow-up to Sower, Parable of the Talents, Lauren creates an Earthseed community called Acorn in the hills of California. The inhabitants live by the creed of Earthseed, learning to prepare themselves for change and to adapt to it. Andrew Jarret, a stern, implacable man bent on returning America to a world where "everyone believed in the same God, worshipped him in the same way and understood that their safety in the universe depended on completing the same religious rituals and stomping anyone who was different" (Talents 20), becomes president of the United States and the popularity of his Christian America movement increases rapidly. The presence of thousands of his extremist followers begins to be felt all across the country. People are attacked and violated for their "immoral" viewpoints and for being "Un-American"; it is only a matter of time before Acorn is overrun by a gang of these "Crusaders". The children of Acorn are taken from their families to be "re-educated", and the inhabitants are abused and imprisoned for their "immoral" lives.

Butler's fear that society is constantly repeating its bad practices is revealed here. Attacks made on "unpatriotic" Americans have become prevalent since the United States was recently placed on alert for terrorist activities. Anyone who criticizes the methods of the current administration is quickly condemned and labeled as disloyal and dangerous. Lauren and her followers are denounced in a similarly extreme way. Lauren 
again acts as a key figure in the middle of this conflict. Like Dana of Butler's Kindred, she is a lone figure struggling to help her people and achieve a balance between the oppressors and oppressed. Like Dana, she does not always succeed in her endeavors but because she is black, because she is revolutionary and because she is a woman, she becomes a target for suspicion and hatred. However Lauren's compulsion to lead is not suppressed. Even in the midst of imprisonment, her community turns to her for guidance. Despite the fact that Lauren's followers endure many months of crushing imprisonment, a sense of fellowship is maintained among the followers of Earthseed and their commitment to adapting to their environment and thus taking control of their own lives helps the majority of them to endure. Lauren is the means of helping them hold on to their faith as she guides them through the hell of their imprisonment. For instance, she warns them against fighting back futilely. Instead she instructs them to remain alert, until they are prepared to fight back as a group. It is because of their adaptability that the group is able to prevail and escape to live again. This ability to adjust is not characteristic of only the Parable series. Butler's heroines in many of her novels are characterized by their ability to adjust to their environments in spite of the severity of changes in their societies. In the words of Ruth Salvaggio, they have "an amazing capacity to compromise" (80).

Butler ensures that Lauren's belief in the necessity to adjust to change and other aspects of Earthseed are brought vividly home to us through the use of Lauren's journal entries. In Parable of the Talents, the narrative is again principally written by Lauren, but Butler also intersperses the story with writings by Lauren's daughter Asha Vere and a few other members of Lauren's family. Lauren's and Asha's writings have the most 
prominence. Both women are natural authors, committing their thoughts, their feelings and key events in their lives to the written page. Ostensibly they are historians. Butler continues the trend evident in $\underline{\text { Kindred }}$ by emphasizing the importance of writers in recording information and ideas. Dana and Kevin of Kindred were both authors, and after their own fantastic experiences, they feel compelled to commit them to paper. In a similar vein, Lauren and her daughter create a narrative which traces the history of the Olamina family, the development of Earthseed and of the United States through years of upheaval and instability. Through their dedication to setting down events, they take on the important duty of recording facts, so their version of history cannot be forgotten and is less likely to be distorted by the machinations of oppressive forces.

The roles of mother and daughter are subversive when compared to old conventions which prevented black people, particularly black women, from contributing to historical records. The task of historian was usually relegated to the white male who was free to present history from his own, often skewed, perspective. Butler turns the tables on these exclusionary tactics, affirming that black women have important contributions to make to the historical record. The detail and sophistication of the narratives of these two women emphasizes the quality and importance of the contributions of black women to the historical canon.

For Lauren, the chance to write her own history has added benefits because it allows her to ensure the perpetuation of Earthseed which is a culmination of her beliefs and her hopes for society; but the religion is radical to many of the fearful conservatives in their superstitious society. Lauren knows that the future of her fledgling philosophy is precarious; without her, it might die out. The attack by the Crusaders proves the fragility 
of her radical philosophy, and the reader is reminded of how aggressively and ruthlessly a fearful society will attack agents of change. Lauren serves as an example of a dedicated agent of change by reporting her ideas and therefore committing herself to acting as a leader to her society. For Butler, agents of change are essential in a society bent on making the same mistakes in a tireless, self defeating cycle.

Through Lauren, Butler also proves her commitment to the education of society. Once Lauren's ideas are written down, they are harder to stamp out. As Earthseed grows, its documentation allows the ideas to be spread. Even skeptical Asha affirms the success of the Earthseed philosophy. Her feelings express Butler's hope for the future: that the dedication of educators will perhaps help society embrace new ideas instead of trying to ignore or decimate them.

Besides the empowerment Lauren gains by writing about her religion, both she and her daughter achieve a deep personal, psychological empowerment from their journals. Journal writing has long been regarded as a therapeutic method to help individuals deal with painful, emotional wounds. Butler emphasizes this restorative technique in Kindred when she shows Kevin struggling to express his experiences in the past. His distress becomes more acute when he discovers that he cannot find the words to illustrate his feelings. He cannot achieve closure or relief. In her article, "The Color Purple: Writing to Undo What Writing Has Done", Valerie Babb associates this curative outlet particularly with the plight of black women. According to Babb, the letters written by Nettie and Celie in Alice Walker's The Color Purple (1982) are not only a form of communication and a symbol of the bond between the two sisters; they are also "a vehicle which lends order to psychological confusion and permanence to transience" 
(110). At times when characters like Nettie, Dana or Lauren feel powerless in the midst of chaos and abuse, they are able to bring some order to their lives by putting their feelings down on paper. While events are happening in a maelstrom, these women authors strive to pin down what has happened by committing the events to paper. As an author, Butler is well aware of the cathartic need to express tormented feelings through the written word. She understands as well, the difficulty sometimes associated with finding the words to express these feelings.

It is significant that at some of the worst moments in her life Lauren often struggles to express how she feels in her ubiquitous journal. After her neighborhood and family are destroyed, she writes a very brief entry, "I have to write. I don't know what else to do...I have to write. There's nothing familiar left to me but the writing. God is Change. I hate God. I have to write" (Sower 141). Later when the community of Acorn is destroyed she writes, "I must make a record of this. I don't want to, but I must" (Talents 203). It is ironic that when she needs her writing the most, Lauren feels most unable to express her feelings. Yet she is eventually able to verbalize her emotions. Butler has her seize control of what is done to her by writing about her experiences and taking her voice back.

Through Lauren, Butler is also able to depict the depth of pain from various forms of oppression which has been inflicted on black women in the past, often suffocating them to the point when silence seems preferable to speaking out. Slave women for instance were prevented from voicing their feelings through many means; however, one of the most effective silencing methods could have been the infliction of pain and abuse which would shame and terrify enslaved women into silence. It is significant that despite 
this pain, Lauren is still able to write about these "unspeakable things unspoken". Like her contemporary, black, feminist peers, Alice Walker and Toni Morrison, Butler is committed to speaking out despite the pain associated with the action.

Empowerment through the journal format is not confined to the characters in Butler's novels; Butler empowers the reader as well. In Parable of the Sower as is usual with first person narratives, the reader is confined to Lauren's doctrine, her perspective, her faith, her religion. Because we are first exposed only to Lauren's ideas and perspective, it becomes easy to fall into her way of thinking, to accept Earthseed at face value. But, it is necessary for different sentiments to be introduced to prevent the narrative from becoming one-sided.

Butler counteracts this tendency by introducing a new perspective on Earthseed in Parable of the Talents. Lauren's journal entries are still the principle storytelling devices of the text, but they are now interspersed with the writings of others. The story begins with a rare essay by Lauren's husband, the man she meets on the way to the site of Acorn and whom she loses during the oppressive occupation of the Crusaders. Taylor Franklin Bankole's brief writing allows him to present some of his own views of the situation in his country and his own uncertainty about Earthseed. His contribution also sets the scene for the rest of the novel which no longer highlights only Lauren's concerns, but those concerns of Lauren's daughter Asha Vere, a young woman striving to understand herself and her history.

Butler intersperses Lauren's entries with the journals of Asha who describes her life and her opinions of the mother she admits that she wanted to love and whom she actually hated, feared and needed but never trusted. Asha is prevented from growing up 
under the tutelage of her mother because the Crusaders steal her from Lauren when they overcome Acorn. Asha is adopted by a Christian America family; therefore, she is able to give something of an outsider's perspective on her mother's movement. She acts as the main questioning voice in the novel, the one who queries the rationality of Lauren's religion. For example she writes, When my mother was a child...she dreamed of the stars...And she dreamed of flying. I've seen her flying dreams mentioned in her earliest writings. Awake or asleep, she dreamed of these things. As far as I am concerned, that's what she was doing when she created her Earthseed Destiny and her Earthseed verses: dreaming. We all need dreams - our fantasies - to sustain us through hard times. There's no harm in that as long as we don't begin to mistake our fantasies for reality as she did...she never doubted the dream, never doubted Earthseed...I can't feel that secure about any religion. (Talents 51) Asha raises questions about Lauren's teachings. She exclaims at the bleakness of Lauren's belief in an uncaring, terrible God and scoffs at her mother's vision of a fantastic, seemingly impossible life among the stars. Above all, she questions Lauren's single-minded commitment which Asha believes causes her to eschew common sense and the needs of her family.

Asha initiates questions many readers may have in their minds or more importantly, she forces us to consider these questions for the first time. She is not the first person in the series to do this, but she is the first who is not presented through the voice of Lauren who is free to distort the views of others consciously or unconsciously. Asha acts as the inquiring unbeliever shedding light on how Lauren's doctrine might 
appear to layman's ears. After inundating us in Lauren's teachings in the first book of the series, Butler shakes the reader with a dissenting voice, allowing Earthseed to be questioned. The reader can find out if the religion stands up to the test, and this is clearly the same type of questioning which allowed Lauren to come to her own conclusions. Butler disregards the blind faith which is encouraged in some religious groups and forces the reader to ask questions about this philosophy, an opportunity they might not be allowed to have in their own faiths.

It was this same blind faith which caused Butler to turn away from the religion of her childhood. In one of her interviews she states,

I stopped believing in the afterlife when I was around twelve... What set me off, I think, was going to church one Sunday - I was raised a born-again Baptist - and hearing the minister read a passage from the Bible and say, 'I don't know what this means, but I believe it.' Somehow you're supposed to believe and have faith but not worry about having any evidence to support that belief and faith. That just doesn't work for me, and I never went back. (61)

Butler transposes her own childhood speculations onto first Lauren in Parable of the Sower then later on to Asha in Parable of the Talents suggesting that questioning is essential to religious experience and not even the doctrine of Earthseed should be adopted without speculation.

In the end, Butler even justifies some of the skepticism of Earthseed by revealing how human traits can warp Lauren's religion. In the very first sentence in Talents, Asha affirms, "They will make a God of her" (Talents 1). Here she is referring to her mother, who becomes revered by Earthseed's followers as the religion gains popularity. In her 
dissertation "Rewriting Christianity: African American Women Writers and the Bible", Adriane Louise Ivey points out that Lauren moves from being a simple member of "a community of misfits" to a religious leader known as the "shaper" in Talents (200). Ivey affirms that Lauren becomes connected to "the same hierarchical system headed by an authoritative God" (201) that she rejected. Ivey sees these changes as evidence of corruption encroaching on Earthseed, but it is also possible to consider these changes as an almost inevitable result of Lauren's religion becoming more widespread.

In many of her interviews, Butler notes that she believes that hierarchy is an inherent and damaging trait of humanity (63); so it is impossible to believe that any movement might not take on elements of hierarchy until society learns to weed this trait out of its innate fabric. Hierarchy notwithstanding, compared to the corruption and horrors associated with Andrew Jarret's Christian America religion, the reader's sympathies invariably lie with Earthseed. As Ivey herself admits, "we are given much more of Olamina's story than of anyone else's. For this reason, we are emotionally involved in the early successes and failures of Earthseed because we get detailed accounts of the early years of the movement and then little about the movement's later rise to power" (205). From all that we can see, Earthseed has more potential to change society for the better than any other movement within the Parable series. In addition, the documented success of Earthseed cannot be overlooked. While the Christian America movement loses its steely grip on the psyche of the country, Earthseed thrives and its destiny is fulfilled within its founder's lifetime. While showing that Earthseed is not perfect or infallible, Butler suggests that it is at least an alternative to the old conventions which could degenerate society. 
It is also important to note that Butler makes the leader of Earthseed uncorrupted. Strong, determined and implacable, Lauren is ideal for setting the machinery of Earthseed into motion. Even though Asha is unwilling to accept her mother's self-proclaimed role, Butler's depiction of Lauren affirms that she believes that someone must take on the role of community leader. Lauren feels compelled to take on the leadership role to ensure that she can pass on her ideas to help others to survive and exist in the erratic, unreliable environment around them. As a type of matriarch, she creates and enforces the rules for her community, teaches them their way of life and leads by example with her amazing capacity to live with change and to shape it. Butler has Lauren accept the responsibility with little compunction once she has accepted the role of Earthseed in her life. In one of her journal entries in Sower, she writes,

Why can't I do what others have done...this thing (This idea? Philosophy? New religion?) won't let me alone, won't let me forget it, won't let me go...And in time, I'll have to do something about it. In spite of what my father will say or do to me, in spite of the poisonous rottenness outside the wall where I might be exiled, I'll have to do something about it. That reality scares me to death. (Sower 23)

Despite Lauren's credible fears, she is motivated by an unquenchable need to take up the burden of responsibility for her community. Like other Butler heroines, Lauren feels moved to take the lead in her community in order to ensure survival and progress. Her devotion to Earthseed is a reflection of many of Butler's other heroines. She feels that she must take on the role. Like many of Butler's heroines, for example Dana of Kindred and Lilith of Xenogenesis, Lauren must face violent opposition and prejudice, but she must 
perform her duty. The black woman acts as the necessary mediator between her own people and oppressive forces. Butler affirms the importance of black women taking proactive roles in their community, despite the opposition, despite the prejudice. Through Lauren, she suggests that this role is integral to the black woman and that it cannot be ignored.

Butler creates dynamic, community leaders and not stereotypical matriarchs as some critics have suggested. In her piece, "The Future of Female: Octavia Butler's Mother Lode", Dorothy Allison expresses exasperation with what she views as Butler's stereotypical portrayals. "What drives me crazy is their attitude: the decisions they make, the things they do in order to protect and nurture their children - and the assumption that children and family come first (471). Butler's mothers do rejoice in their children with familiar, motherly emotions. However Allison only associates this preoccupation with children with stereotypical maternal feelings.

There is no doubt that fierce, dedicated, motherly emotion fuels the actions of many of Butler's heroines, but there is more to this mothering than the stereotype suggests. As Patricia Melzer observes in "All that you touch you change': Utopian Desire and the Concept of Change in Octavia Butler's Parable of the Sower and Parable of the Talents", "Butler's concept of mothering rejects the white stereotypical ideal of the nurturing, self-sacrificing mother within patriarchal society. Instead, it embodies involvement and commitment to the community at large that in principle is independent of gender" (42). Besides having an interest in children for their own sake, Butler's heroines place their hopes in their children because they will perpetuate the community. Alice of Kindred had this hope. For her, her children were symbols of the freedom she 
could not achieve herself. She cared for them, not only from a motherly standpoint, but because if the hope that they would represent the free black community she herself had been born into. This philosophy that posits children at its center acts as a foundation to ensure the community has a future.

Asha's and Lauren's entries both verify that the children of Acorn are thoroughly educated in practical subjects and presumably in the writings of the Earthseed philosophy as well. Lauren loses no chance to instill her teachings in the younger members of the community. She sees the necessity of passing the teachings of Earthseed on to older people who can disseminate the information around the people they meet. Children can do the same, but they also have the added benefit of being young enough to use the information effectively and pass it on to their own children during their lifetimes, effectually keeping Earthseed alive. Lauren understands this concept perfectly. She remains practical despite her fantastic predictions. She knows that her hopes cannot be easily achieved, and as time goes by she worries that these fears will not be fulfilled while she is still alive. Therefore the only hope for Earthseed is in the children they produce. When these children are stolen from the community, the Crusaders have not only broken the hearts of the parents of Earthseed, they have dangerously threatened the future of the community's hopes and dreams.

These "descendants of Earthseed" prove their worth when the community begins to replenish itself. Asha explains,

She kept her word. She never stopped teaching. For Earthseed, she used herself up several times over speaking, training, guiding, writing, establishing schools that boarded orphans as well as students who had parents and homes. She found 
sources of money and directed them into areas of study that brought fulfillment of the Earthseed Destiny closer. She sent promising young students to universities that helped them to fulfill their potential. (Talents 443) Lauren is clearly working feverishly to make sure that she has enough "children" to keep Earthseed alive, and her concerns are justified by the fact that when the first shuttles leave for the moon, few of the original members of Acorn are alive or old enough to go to nurture the community. Lauren herself is 81 and does not go because she believes that she could not survive as "something other than a burden" (Talents 445 ), but she believes that she has achieved her goal of ensuring that her religion survives. The children of the original members of Acorn are prepared to further their parents' mission of forging into a new world. Dorothy Allison does not take this practical concern for the community memory into consideration when she disparages Butler's mothers and their gendered roles.

The importance of preparing children for the future is only one facet of Butler's conception of activism as inducement for social change. Despite the fact that Lauren's ultimate goal seems distant and almost unattainable, she does not believe in passively waiting for destiny to be achieved. This contradicts the concept of the option of "shaping change" which is recorded in the doctrines of Earthseed. The future is Lauren's singleminded purpose, but it will not come to the followers of Earthseed; they must work to fulfill the Destiny. In Talents, Lauren uses modern technology as a tool to achieve her goals. For example, her Earthseed Destiny is an innovative, visionary, settlement on the moon which must be financed and developed. The movement is eventually able to realize this goal. At the end of the novel, the settlers board prototype shuttles carrying 
"frozen human and animal embryos" (Talents 363), so they are again using progressive and radical methods to achieve their purpose.

Besides her uses of advanced technology to further her teachings, Lauren begins to canvass her movement more actively. Patricia Melzer notes that "Earthseed utilizes traditional liberal forms of political strategies including outreach projects, door to door campaigning, city hall events, and speeches at schools and universities, and the publication of Earthseed - the Book of the Living" (Talents 46). After witnessing the result of isolating her community, Lauren learns from her mistakes and begins cultivating the interest of influential people who help her spread her teachings. "I've reached so many people" she writes, "from Eureka to Seattle to Syracuse that I believe that even if I were killed tomorrow, some of these people would find ways to go on learning and teaching, pursuing the Destiny" (Talents 430). Lauren has already witnessed the consequences of stagnation in her childhood community and pushes for progress, always looking forward to the future. As a consequence, Earthseed heals and thrives. Butler is aware that activism can bring healing to society, and Lauren actively lives her policy of "shaping change".

As Lauren watches these children launch themselves into a new life, it is impossible not to associate her closely with her creator. Like Lauren, Butler fears that society is going in the wrong direction, "playing an antiquated record". Like Lauren, she feels that society must make radical changes within itself to override its destructive inner programming. She told Stephen Potts, "in Parable of the Sower I focused on the problems - the things we have done wrong, that we appear to be doing wrong, and where those things can lead us...In Parable of the Talents I want to give my characters the 
chance to work on the solutions, to say, "Here is the solution!" (336). In creating a solution based on the future, she departs from the focus of her peers. Writers like Toni Morrison and Alice Walker have concentrated on looking back at the past to find the healing for the pain of oppression. Butler does not dispute the importance of being aware of the path we have taken, but she also has her far seeing eyes fixed firmly on the way yet to come. Like her creator, Lauren, the shaper, the mediator, the leader stands at the crossroads leading to society's potential. She points the way to a future she hopes will be better, that she hopes will bring changes which will draw humanity away from deterioration and loss. 


\section{IV. "Our Children Will Be Better Than Either of Us": Oppression, Miscegenation and Mediators in Octavia Butler's "Dawn"}

While the Parable novels focus on the changes society must make to change our prospects, Octavia Butler's Dawn (1987) explores the reasons that human beings seem to be resolved on creating a society based on intolerance and class boundaries.

In her review of Dawn the first book in Octavia Butler's Xenogenesis series, Rachel Pollack observes, "Unlike many sf writers who deal in ethical issues Butler presents more questions than answers" (70). Pollack also implies that this propensity to question is the beauty of Butler's work, that Butler sometimes suggests solutions for the problems of humanity as she does in the Parable novels, yet she is also extremely aware of the imperfections that would be inherent in many of humanity's solutions.

Unlike many of her peers in the African American canon who focus on realistic portrayals, Butler's questions act as an exploration of "what ifs" which can be acted out through the speculative landscape of science fiction. Through the fantastic situations she creates, Butler is able to depict societal issues of ethics and power which are familiar and poignant to black people, particularly black women. In Dawn as in many of her other novels, the heroine of this novel acts as leader and mediator for the good of the community, struggling with conflict within herself and with the opposing sides she is trying to appease.

Key societal and race issues in Dawn come to the fore at the end of the novel when Butler's heroine Lilith Iyapo discovers that she will become the mother of the first alien hybrid or construct: a mixture of both human and the alien species, the Oankali. It is a phenomenon Lilith resists from the moment she learns of the Oankali's drive to mix 
their genes with the other species they encounter, yet her alien friend Nikanj decides that Lilith's time is right and uses its control of her body to inseminate her. "Our children will be better than either of us" it tells her. "We will moderate your hierarchical problems and you will lessen our physical limitations. Our children won't destroy themselves in a war, and if they need to regrow a limb or to change themselves in some other way they'll be able to do it. And there will be other benefits" (Dawn 243). Like other Oankali, Nikanj's words are always calm and outwardly reasonable. Through the alien, Butler depicts her own interests, as affirmed in Chapters II and III, in the need for the human race to embrace change and adaptation to survive.

As a step beyond the Parable novels, the society in Dawn must not only change its habits but its genetic structure. Many humans are violently opposed to embracing the radical change the Oankali propose. Like many groups in Butler's novels, they are suspicious of change, preferring the comfort of the familiar. Because of the Oankali's "alienness", the human beings believe them to be unnatural and therefore immoral. As a result, they fear that an alliance with them will force the humans to compromise their beliefs and their humanity. In this chapter, I claim that Butler implies that major sacrifices of autonomy may be necessary to ensure the survival of both the individual and of the community. In a common link with her other novels, she portrays a black woman as the mediator in her narrative, a woman who feels compelled to take the lead, to allow progress even though she is seen as a traitor to humanity because of her actions. At the same time, Butler does not discount the extent of the pain of the sacrifice of autonomy, paralleling the machinations of the Oankali with the master slave relationships of the antebellum South. Her narrative is ambivalent and complex; the text suggests a utopian 
vision, but at the same time Butler's narrative landscape is plagued by the undercurrents of oppression and human imperfection. She manages to provoke the reader to be disturbed by these nuances which are intrinsic in our contemporary society but which we may otherwise be inclined to ignore. Since Butler presents these issues in the context of the future of mankind, we cannot help but be disturbed by the knowledge that oppression still exists in modern society, though often in less insidious forms than in the past, and if we do not at least recognize it, it may stay embedded in society's structure.

The first major event which diverts the path of humanity is a nuclear holocaust between nations which nearly wipes the human race out. Only the intervention of the Oankali prevents complete extinction. Driven by an innate desire to assimilate with other races, they gather all living humans they can and heal and study them while keeping them in stasis for many years. Their eventual goal is to make the earth fit for human habitation once more. The planet can then be used to house humanity and the hybrid offspring of humans and Oankali. Therefore the Oankali are saviors of the human race and offer them a chance at renewed and enhanced life.

When the Oankali awaken a black woman named Lilith to act as a mentor and leader to the first groups of humans who have been chosen to populate the earth, she discovers the extent of the "benefits" the Oankali offer the human race. The extraterrestrials can alter the human body by enhancing human abilities and longevity. They can heal illnesses like cancer. They seem to have the answers for every human problem including the reason why humans are so often moved to destroy each other. One of the Oankali tells Lilith that humans naturally have the mismatched characteristics 
of intelligence and hierarchy which propel them to self destruction. The Oankali observes,

When human intelligence served it [hierarchy] instead of guiding it, when human intelligence did not even acknowledge it as a problem, but took pride in it or did not notice it at all...That was like ignoring cancer. I think your people did not realize what a dangerous thing they were doing. (Dawn 41)

Butler gives more examples of this human propensity to categorize others, to impose dominance on those who are perceived to be "other" in an interview with Larry McCaffrey. She explains, "we get hung up on who's got the biggest or the best or the most, on who's inferior and who's superior" (63).

Apparently both Butler and her fictional progeny the Oankali, feel that this tendency to oppress others prevents human beings from growing beyond their self destructive path. They both believe that humans cannot completely overcome their genetic "flaw." For the Oankali, it is necessary to breed the "hierarchy" trait out of the humans. As already noted, the construct children who are born from a mixture of human and alien are free from the competitive need to wreak the destruction of human societies. In the next volumes in the Xenogenesis trilogy, Butler depicts the human/Oankali communities living in villages in close, loving family units. The units live in close harmony with each other and their environment. They embrace humans, Oankali and constructs, reveling in the diversity of their community. Theirs is a world of flexibility and adaptability.

The communities of the humans who refuse to adapt to these changes suffer because of their very determination not to submit to change and embrace the differences 
of the new species emerging in their midst. When they are awakened, many humans are suspicious of their new environment and their "captors". At first, some ally themselves with Lilith who is outwardly trying to teach them to cooperate with the Oankali, so they will be prepared to survive on the new Earth, and surreptitiously encouraging them to escape from the Oankali whenever the opportunity arises. More than any of the other heroines discussed in this work, Lilith is seen as a traitor because of her compliance with the Oankali even though her motives are simply to ensure the survival of mankind, and she is willing to defy the Oankali to help the community. Another large movement chooses to resist Lilith and the Oankali influence, rejecting all help they can give. When they are taken to an area of the Oankali spaceship which resembles earth, many of them ignore Lilith's warnings that they cannot escape the area and flee.

The humans' fear of the difference the Oankali and Lilith represent foregrounds the xenophobia within these "resister" humans, a xenophobia that drives them to panic and fear. It is ironic that because of some biological enhancements, many of the humans fear that Lilith is not human while she is actually trying to preserve a branch of the human race. Butler's mediators are usually alienated because they are black and because they are female. Lilith becomes even more "other" because of this added diversity. Her increased alienation underlines the marginalization of black women who choose to become leaders. It reflects the fact that this alienation seems to be a natural element of the role of black, female leadership. Until society is willing to see the black woman as anything besides the "other", this attitude will continue to perpetuate.

The extent of this "xenophobia" becomes apparent in the case of Lilith's lover Joseph, an Asian man who supports her cause. In an appalling scene which takes place 
off screen, Joseph is hacked to death by a human who sees his wounds swiftly healing (a result of the biological enhancements the Oankali have implanted within him).

Describing the incident to Lilith, Nikanj explains, "he saw Joseph healing, saw the flesh mending itself before his eyes. He screamed. I've never heard a human scream that way. Then he...used his ax" (Dawn 221). Refusing to bend to change and difference, the fearful man is driven to commit murder. Because they cannot tolerate his prejudice in the society they hope to build, the Oankali take him back to their ship where he will live in a constant drugged, semi conscious state for the rest of his life. As in her other novels, Butler does not tolerate an obtuse, unbending dedication to old ways, and intolerance of differences. Through these incidents and others throughout the trilogy, she suggests, that embracing difference and diversity brings hope and productivity while a reluctance to embrace diversity provokes sterility and stasis.

Therefore on the surface, with their desire to find an alternative existence for humans and to establish peaceful, violence-free family communities, the Oankali seem like a species of guardian angel from the heavens. Some critics have identified them as embodiments of Butler's utopian visions. With their advanced technology and their dedicated purpose, they gently take control of the human race for their own good, but it is in this gentle guardianship that the disturbing undertones of the Oankali purpose become apparent.

Beneath the Oankali's apparent gentleness and concern, there are undercurrents of self-righteousness and a predilection for dominance (itself a component of hierarchical behavior). Their behavior in fact is not unlike the behaviors of oppressive facets of human societies. In Kindred, many of the whites mirror the machinations of past and 
modern day prejudice as they brutally exercise their power over the blacks of the plantation. In the future world of the Parable novels, the members of the Christian America sect act out extreme self-righteousness. The Oankali never employ the same level of violence, but their dominating behavior cannot be ignored.

Many critics perceive similarities between the Oankali/human relationship and slave/master relationships in the antebellum South. Faced with such an analysis, Butler herself might not agree. When Larry McCaffery suggests to her that her books all deal with slavery and domination she disagrees, citing her novels, $\underline{\text { Kindred }}$ and Wild Seed (1980) as her works that deal specifically with slavery. She states, "'I don't agree, although this may depend on what we mean by slavery" (56). She goes on to describe slavery as "humans being treated like possessions" (57). However, while Butler's main concern while she was writing Dawn was not the depiction of slavery, elements of this type of relationship of submission and domination are still apparent. For example, in her discussion of Butler's novella, Bloodchild (1995), Elyce Rae Helford acknowledges Butler's definition of slavery, but adds, "I believe that McCaffery is right to point to this powerful theme in Butler's fiction. When the aliens control your destiny as fully as the Tlic [the aliens in Bloodchild] control the humans, I call it enslavement" (266). Ironically, the same can be said for the Oankali who, like the Tlic, have a firm grasp on human destiny, imposing their will on them even to the point of controlling their bodies.

A good example is the Oankali's single-minded devotion to interbreeding with humans. In her article, "Difference and Desire, Slavery and Seduction: Octavia Butler's Xenogenesis", Frances Bonner points out, "just because the Oankali claim to have avoided hierarchies, it does not mean they have eschewed power" (56). The humans no 
longer have any say in the path they have to take in the future. The Oankali have decided that they will become a new species through their interbreeding, and as Bonner ironically observes, "The Oankali know best" (56). Both Bonner and Rachel Pollack point out that in some ways the Oankali viewpoint is justified since allowing humans free reign over their lives has brought about disaster in the past. Butler does not believe that any humanled movement can exist without hierarchical behavior. (Even when she created her "ideal" religion in the Parable novels, Butler introduced hierarchical elements in its structure.) She suggests that the patriarchal Oankali might be right in their assessment of the destructiveness of human beings. It is easy to see them as the "good guys", to accept their way of thinking, yet they deny human beings choice and autonomy, and this loss is key in Xenogenesis.

For example in many instances in Dawn, the Oankali often ignore Lilith's suggestions and pleas, believing that they know best. Several times, they are proven wrong. In her review, Rachel Pollack observes, "As inferior, childlike creatures, humans supposedly do not need to make their own decisions. All this recalls that favorite White American fantasy, the benefits of slavery for the happy Blacks" (70). White masters on antebellum Slave plantations often justified their actions by observing that slaves were incapable of taking care of themselves. It seems that the Oankali have the same excuses. As seen in the Parable novels, Butler believes in the human ability to "shape" change The Oankali deprive the humans of control over their own destinies in a system which seems oddly familiar and more than a little disquieting. The close control the Oankali hold over human biology is also a familiar element of plantation culture. Slave owners decided when slaves were ready to procreate, forcing them to interbreed and reproduce at 
their masters' will. They had free reign to inflict sexual abuse as they pleased. For them the slaves of the plantation were merely breeding animals to be used solely for their benefit.

The Oankali however have a greater control than plantation owners could ever achieve because by nature they can easily manipulate human biology. When Lilith discovers that the Oankali have discovered and eliminated the beginning of a cancerous growth in her, she is relieved, but her sense of violation is stronger. "It scares me," she says, "to have people doing things to me that I don't understand" (Dawn 36). Her fears are justified, for again the Oankali have allowed their patriarchal ideas of what is right dictate their actions. All the humans are sterilized before they awaken. They can only have children when an ooloi (the third sex of the species) alters their bodies to begin the natural reproductive process. According to the will of the Oankali, when the humans are allowed to have children, they will be human/Oankali constructs. When Lilith first learns of this, she is understandably troubled, demanding, "What will you make of us? What will our children be?" (Dawn 44). She adds, "I don't care what you do with what you've already learned - how you apply it to yourselves - but leave us out of it. Just let us go" (Dawn 44). Lilith's plea is not dissimilar to the feelings of a slave on a plantation, longing for freedom for themselves and their children, but the Oankali are not moved to provide them with an alternative. So it is no surprise when later on the ooloi Nikanj impregnates Lilith without her knowledge. "Is it an unclean thing that I have made you pregnant?" it asks Lilith. It adds, "I have made you pregnant with Joseph's child" (Dawn 242). This occurs after the murder of Joseph and when Lilith becomes wearied of the hatred and hierarchy of the human race, so at first the reader can see this as a violation of 
a human body, but the reasonableness of the Oankali has some justifications. The children of human and Oankali would be free of these terrible, self destructive behaviors which can destroy the human race. It is difficult for the reader not to wonder if the Oankali do not have the right idea even though their methods may be questionable. Butler stays true to her efforts to probe the shadings of good and evil, but she gives the reader no easy answers.

Nikanj's motives are at one level compassionate. It has provided Lilith with a daughter, a reminder of the lover she lost. It is also convinced that Lilith secretly welcomes this child. It is trying to help her. When Lilith protests, it calmly asserts, "you are ready to be a mother. You could never have said so" (Dawn 242). However it is impossible for Lilith and the reader to forget that the child has been imposed on her. The alien remains staunchly patriarchal assuming that it knows Lilith even better than she knows herself. Images of slave men and women used as breeding animals come vividly to mind during scenes like this. Slave masters upheld the notion that women were breeding machines. Their views however were pervasive in society for decades after slavery was over and still persists in many cultures.

The Oankali do not exercise the same belief that women are conversely weak and naturally less intelligent, but they seem to exercise the disturbing notion that a woman should not have a choice in whether she should be a mother or not. The fact that in later volumes, Lilith admits that she did indeed want a child complicates the impact of the situation. In her article "Polymorphous Futures: Octavia E. Butler's Xenogenesis Trilogy", Amanda Boulter likens Butler's depiction of the Oankali's use of the human race as a parallel to the "violent history of miscegenation in the United States" (178). She 
adds, "Miscegenation is a charged category in the history of black oppression in America, evoking various violations of reproductive freedom and integrity, including rape, incest, forced sterilization, forced pregnancies, lynching and murder, human experimentation, and child abuse" (178). Butler's illustration stirs up old fears and concerns on this layered and controversial concern. Black people particularly may be moved to experience racial melancholy since the history of miscegenation so often brings up feelings of pain and bitterness. As Lilith struggles with her feelings, she echoes the apprehensions of countless women who have had to face similar conflict in regard to forced pregnancy. There can be a complicated mixture of longing and loathing associated with a child conceived by oppressors, and Lilith is plagued by these feelings. Butler later enhances the complexity of the situation when Lilith admits that though she welcomed her child she still felt that Nikanj should have left her alone. By awakening these fears in the reader, Butler forces them to face these relevant issues of abuse of female biology once more.

However, while invoking the pain of the past, Butler "redefines the values and possibilities of the future" (Boulter 179). While miscegenation awakens racial melancholy, the union between human and Oankali does not share all of the parasitic elements of plantation sexual abuse. In her interview with McCaffery, in reference to Bloodchild, Butler affirms that she is talking about "symbiosis" (56). Both groups experience benefits because of the connection. The relationship in Xenogenesis has some similar traits to the alien/human relationship in Bloodchild where the human Gan becomes aware of the symbiotic dependence the Tlic have upon his species because they use human bodies to incubate their offspring. He struggles to maintain an uneasy alliance 
with his own alien mentor, acting as a male version of Lilith. In Xenogenesis, the symbiotic relationship is just as pronounced but more loving. The Oankali deeply desire a connection with humans. It is their nature, and they cannot do without the connection. In return, the humans are drawn into productive, peaceful community relationships. This is emphasized in the next two volumes of Xenogenesis when we see Lilith acclimated to her life with the Oankali though she is never completely free of the apprehension that she has sacrificed humanity by allowing the inter dependence to grow.

These later volumes also prove that Butler is setting the scene for a change in Oankali psychology. In the next volume Adulthood Rites, Lilith's construct son manages to convince the Oankali population that humans deserve the chance to have free will, to maintain a purely human race if they wish. The resister humans are given the option of living in Oankali communities or creating their own human communities on Mars. The Oankali allow this despite the fact that they still believe that their theories about humans are correct, that the community is doomed to failure even before it has begun.

In the end Butler emphasizes her belief in free will and autonomy, suggesting that society should not tolerate regulations which bar the right for individuals to make a choice. The Oankali's willingness to change their belief system contrasts with the inflexibility which is often tolerated in society. Butler implies that the Oankali have improved as a race because of their willingness to adapt. Through the resisters, she has already shown how intractability can destroy a race, and we are reminded that our own society is following this path to destruction. The Oankali achieve peace with the humans and bring hope and contentment to the humans and their children who live among them. Butler implies that adaptability may well be the solution to society's repetitive self- 
destruction. She suggests that if some sacrifices are necessary to achieve this type of peace, perhaps these sacrifices may be worth it.

What turns out to be more problematic than the depiction of the future of the human race is the Oankali approach to sexual relationships. The sexual experience with the Oankali is a mainly sensorial affair which can involve groups of two or more humans and one or more Oankali linked by the alien's sensory tentacles. The ooloi triggers the sensory pleasure of all participants and shares the experience with each individual.

She never knew whether she was receiving Nikanj's approximation of Joseph, a true transmission of what Joseph was feeling, some combination of truth and approximation, or just a pleasant fiction. It seemed to her that she had always been with him. She had no sensation of shifting gears, no "time alone" to contrast with the present "time together"...Nikanj focused on the intensity of their attraction, their union. It left Lilith no other sensation... She sensed only Joseph, felt that he was aware of her. (Dawn 159-60)

For the humans the experience is a terrifying mixture of pleasure and often terror because they experience this pleasure which seems unnatural and forbidden. When drugged by the Oankali sedatives, they are relaxed enough to enjoy the encounters, but when they are fully conscious, they are assailed by guilt, homophobia and a sense of violation. The men complain fiercely and fearfully of a control that they feel is emasculating. While defending his peers, one of Lilith's friends exclaims, “"Look at things from Curt's point of view...He's not in control even of what his own body does or feels. He's taken like a woman...He knows the ooloi aren`t male. He knows all the sex that goes on is in his head. It doesn't 
matter...Someone else is pushing his buttons. He can't let them get away with that"'. (Dawn 201)

The fact that the men of the group cling to old world notions of homophobia emphasizes the violence and discomfort related to the intolerance of difference. Butler understands the discomfort associated with the new experience, but she pushes acceptance of it. The sex is portrayed as loving and sensual, and the characters who oppose it are given negative treatment. Lilith herself eventually learns to welcome the contact. Here again Butler does advocates a gradual acceptance of diversity and difference.

The critical response to this "alien sex" has been equally complex. In her review of Dawn and Adulthood Rites, Adele Newson calls the union between Lilith, Joseph and the ooloi, Nikanj, "a refreshing approach to human relationships" (392). From a feminist perspective, the union erases the role of dominance in everyday sexual intercourse and challenges notions of heterosexuality since the experience can involve so many sexes as well as the asexual ooloi. Butler is clearly aware of the underlying uneasiness these strange unions provoke. She deliberately pushes the boundaries of conservative viewpoints, forcing the reader to explore them as well.

In addition, the reader is made to share the sense of loss of the characters because intercourse no longer involves physical human-to-human contact. After joining with an ooloi, the humans become naturally averse to physical contact with one another. At one point in the narrative, Lilith

Is bothered by the care he [Joseph] took not to touch her. She reached out and touched his face to make him turn toward her. Instead he drew away. Worse, if he had not drawn away, she would have. His flesh felt wrong somehow, oddly 
repellant. It had not been this way when he came to her before Nikanj moved in between them. Joseph's touch had been more than welcome. He had been water after a very long drought. But then Nikanj had come to stay. (Dawn 217) Here the poignancy of the loss of the human experience becomes particularly acute. Despite the fact that Butler believes that only radical change will bring progress to humanity, she is well aware of the sacrifice and irretrievable loss involved in this necessary change.

However, many critics are not as certain of Butler's position on the coercive element of Oankali sex. In "The Future of Female: Octavia Butler's Mother Lode", Dorothy Allison sees the union between human and Oankali as "the answer to sexual violence" (477). She enthusiastically writes, "Without the need to impose a hierarchal male dominant/ female submissive structure on sexuality, the Oankali approach the act with a genuine sense of joy equally shared. Nothing is sinful, nothing is forced. Everything is committed except violence" (477). However although there is no violence, it does not follow that there is no coercion.

The Oankali's gentle but firm approach to sexual seduction is another example of their patriarchal insistence that their way is best despite objections. Frances Bonner rightly describes the Oankali intercourse as a rape called by another name (57). The Oankali use their mastery over human biology to lull humans into submission. During her discussion of Nikanj's "seduction" of Joseph, Bonner asserts, "Throughout the trilogy much is made of Nikanj's powers of seduction... but this is also our first opportunity to observe an ooloi 'seduction' and I for one certainly find the scene, in which a drugged man is subjected not just to casuistry but to a 'poor little me' turn from a misunderstood 
alien, a little hard to take" (55-6). As in the case of Lilith's pregnancy, Nikanj affirms that Joseph wants the sexual contact. As Rachel Pollack observes though, this is often the stance taken by rapists in their fantasies: "the woman really wants it, and only says no because of social conditioning, that in fact she will be grateful and surrender with overwhelming passion to the man who makes the decision for her" (70). Bonner is clearly disturbed by this coercive element, but she is particularly perturbed because she is not certain if Butler is aware of the discrepancies in her illustrations (58); however, Pollack suggests that this is part of Butler's depiction of the patronizing attitude of the Oankali. Her stance verifies Butler's concerns in regard to the human/Oankali relationship. The Oankali position when it relates to intercourse with humans is typical of their attitudes in all other things. Generally when humans resist them, they stubbornly and gently persevere until their will prevails. Butler takes pains to show this aspect of the race. Why would they change tactics in this the vital element of their interaction with human beings? True to her usual exploration of the complex and uncertain, Butler makes this interaction a mixture of fear and pleasure, and she is fully aware of her contradictions.

In the midst of this environment of radical change, Butler again sets a black heroine at center stage. By bestowing this heroine with the name of Adam's rebellious first wife, Butler sets the scene for Lilith's role as unwilling traitor and an agent of change. The biblical figure also shares her role with Lilith as "mother" to a new race. The Oankali recognize her for her leadership qualities, bestowing her with the task of awakening the humans from suspended animation. The process of awakening each person and acclimatizing them to their environment has unmistakable parallels to birth. 
For instance, Butler writes, "Slowly, the face and body of Tate Marah became visible...She would not awaken until she was lifted completely clear of the suspended animation plant. Her body was wet and slippery, but not heavy. Sighing, Lilith lifted her clear" (Dawn 125). Lilith goes on to train the awakened humans to survive on the new Earth. She must make decisions for them and discipline them while hoping that they will learn to build a community and eventually escape from Oankali control. She is Butler's conception of a type of matriarch which populates her novels: a woman leading and preserving her community.

Later when Lilith abandons her role as mentor, she continues in the footsteps of the biblical Lilith - who abandoned Adam and gave birth to demon children with her new husband - by becoming the first mother of the construct children, who are demons and abominations in the eyes of the resisters, but who are actually symbols of a different future for this new branch of the human race. Dorothy Allison sees this as evidence of Butler's obsessive interest with mothers and mothering. She describes the eventual acceptance between the humans and aliens as "the dream of an ideal family, the mother making possible her children's lives and freeing them to choose their own destinies" $(478)$.

However, as noted in a previous chapter, this stance ignores the fact that Butler also apparently sees the black woman, as an essential community leader. Like Lauren of the Parable novels, Lilith acts as a teacher and an advocate of change. She is the voice of Octavia Butler, teaching the importance of adapting to change. While others crumble and weaken under the astonishing conditions, Lilith is able to adjust to the sacrifices and pain associated with their new life. Just like other Butler heroines, submission is not her goal 
but survival. Even as she agrees to mentor the human groups, she secretly plans to warn them to escape from Oankali dominance as soon as they have free range of the Earth once more. When she feels that she can no longer handle the role of leader any longer she makes the decision to quit, shaping her own destiny while she can. She manages to stay alive despite the odds, and she becomes an example to other human beings who eventually choose to adapt to this new change as well.

It becomes particularly clear here that the role of the black woman is "selfimposed" as Adele Newson suggests (391). The Oankali give Lilith little choice in whether she will be the leader of the new settlers, but the fact that she is able to renounce the role in the end suggests that she could have resigned long before. Even when Lilith joins a group of humans trying to break away from the Oankali and strike off into wilderness on their own, Lilith automatically takes charge "out of habit" (Dawn 215) although they are temporarily away from Oankali control. Her role as leader is a thankless one; Lilith legitimately complains of being the "Judas-goat" (Dawn 237), forced to be the traitor among her own people, but she still makes the decision to take on the position despite its implications.

As she does with Lauren of the Parable novels, Butler portrays the role of the mediator as a natural one inherent in the subconscious of her black women. Despite the dangers, the alienation and the pressures they must face, her characters feel they can best serve their communities by taking the lead. Their success is rarely absolute, but survival ultimately endures, and the community prevails and has a chance to progress. Butler seems to suggest that someone must play the role of a "go-between" or rather an agent of change to make sure progress continues despite the resistance of those dedicated to stasis 
and stagnation. As advocates of change in their own communities and homes, black women seem to have chosen to take on this role.

In her own way, Butler is also a mediator. Her work never presents clear cut issues; she dabbles in fuzzier areas. In her interview with Larry McCaffery, she explains, "What I hope to wind up with in my work are a series of shadings that correspond to the way concepts like "good" and "evil" enter into the real world - never absolute -, always by degrees" (64). In Dawn she achieves this balance in her benevolent aliens who are oppressors and saviors in one, and in her conflicted characters trying to survive and who never gain complete satisfaction whatever the path they take. Her goal is not to provide solutions but to tease out the complexities of the issues she isolates. Through science fiction, she is particularly well equipped to look backward and forward to find her questions and entertain some answers. She leaves her readers to understand what she sees and draw their conclusions on their own. 


\section{Conclusion}

If Octavia Butler's readers could physically step into the midst of her literary

landscapes, they might immediately be assailed by the bleakness, despair and hatred that permeate the atmosphere. It cannot be denied that the environments she creates are rarely inviting or overtly utopian, but there are elements of hope apparent in her texts.

The conditions the heroines examined in this work have to face support Butler's anti-utopian perspective. In Kindred, Dana yearns to escape from repeated journeys into the past where her physical safety is not only threatened, but where she must face the anguished history of her ancestors and struggle to improve the quality of their lives. In the Parable novels, Lauren Olamina understandably withdraws from the violence and intolerance which characterizes post-apocalyptic America and tries to create an idyllic community in the mountains only to have the fascist elements of the government try to destroy the home she hopes to build. Lilith Iyapo awakens in Dawn to find the world she has always known destroyed by her own society's obsession with dominance and subjugation.

It is not surprising that many critics believe that Butler's oeuvre is delineated by this hopelessness and the belief that society is destined for destruction. For example, in Hoda M. Zaki’s article, “Utopia, Dystopia, and Ideology in the Science Fiction of Octavia Butler" she suggests, “that Butler's dystopianism is pessimistic not because Earth and its civilizations are almost lost, but because the causes of catastrophe are depicted deterministically as unavoidable" (244). Butler's discussion of hierarchy in her

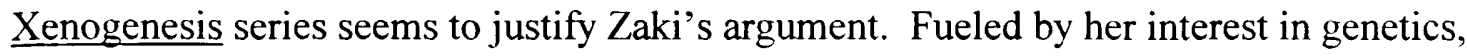
Butler believes that much of society's dominant behaviors must be bred out of us as the 
aliens of Dawn suggest. However, elements of Butler's narratives are not as completely deterministic as Zaki suggests. Instead of suggesting that there is absolutely no hope for society's future, Butler envisions humans with the ability to make inroads in the downward path society is traversing. While their contributions may not divert this journey to self destruction completely, some hope can still exist in this dystopian landscape.

The key to this chance for modification lies in Butler's black heroines who stand at the crossroads which could lead to society's degradation or to a world which embraces tolerance, diversity and autonomy. These heroines are the leaders who are despised, feared and occasionally loved for taking on their roles as guides for their communities. Although their positions entail hatred, pain and marginalization, Butler's protagonists feel compelled to adhere to their duties as community leaders. They know that their contribution means survival for their children and their families; they realize that they can create a better quality of life for themselves and society, and they can achieve the autonomy and peace that they yearn for. If they do not accept the role as guide, it is likely that humanity will continue along the path of loss and pain instead of turning down the more hopeful track to survival on the crossroad.

Butler's women lead by example. They learn to adapt and bow before oppressors while quietly gathering their weapons for the definitive strike which will gain them their autonomy as Lauren does in Parable of the Talents when she is imprisoned. They accept and welcome diversity in others, recognizing that these differences can improve society's structure and chance for survival as Lilith learns to do in Dawn. They advocate productive changes in society's philosophies and regulations, recognizing when radical 
transformations must be made to prevent society from continuing a stale cycle of self hate and tyranny.

These are the women who are willing to make the painful decisions which may perpetuate community life and ensure that our children and therefore our history will not be lost or squashed beneath the force of oppression. They are the women who are willing to risk opposition and abuse because they realize that we must begin changes in our society before it is too late.

They are the strong black females, Butler envisions for our communities. Close observation of the inroads made by oppression and prejudice has made her realize how important such women are to the African American community. She realizes that the opposition imposed upon female community leaders is an attempt to deflect the relevance of their contribution to society, but within her narratives, she insists that they continue to advocate change in our society.

These women must deal with society's inevitable imperfections. Butler herself affirms, "I've actually never projected an ideal society. I don't believe that imperfect humans can form a perfect society" (Beal 14). However, she does believe that if women take up the position as guides, there is hope that some of her dystopian fears of a complete descent into fascism can be averted.

Therefore Butler's contribution to the African American canon is a vivid depiction of potential catastrophes for our present day societies and the active roles we must employ to try to protect ourselves. Some of society's missteps may be inevitable, but if the black, female community acts, there is a chance that they can take power into their own hands and turn society into a different and hopefully better direction. Like her 
heroines, Butler advocates change and hope in her novels, but she affirms that this opportunity can only be achieved if society's women assume the role of guides and fearlessly lead the way to a different world. 


\section{Bibliography}

Babb, Valerie. "The Color Purple: Writing to Undo What Writing Has Done". Phylon. 47 ( $2^{\text {nd }}$. Qtr., 1986): 107-116. JSTOR. FIU Libraries, Miami, FL 18 May 2004. http://www.jstor.org/

Bambara, Toni Cade. Interview by Zala Chandler. In Wild Women in the Whirlwind: Afra-American Culture and Contemporary Literary Renaissance. New Brunswick: Rutgers P, 1990.

Bell, Benard W. "Beloved: A Womanist Neo-Slave Narrative; or Multivocal Remembrances of Things Past," African American Review. 26 (Spring 1992), 7-15. JSTOR. FIU Libraries, Miami, FL 7, February 2004. http://www.jstor.org/

Blieler, Richard. ed. Science Fiction Writers: Critical Studies of the Major Authors from the Early Nineteenth Century to the Present Day., New York: Macmillan Publishing USA, 1999.

Bonner, Frances. "Difference and Desire, Slavery and Seduction: Octavia Butler's Xenogenesis." Foundation: The Review of Science Fiction, 48 (1990) 50-62.

Braxton, Joanne and Andree Mclaughlin, eds. Wild Women in the Whirlwind: AfraAmerican Culture and Contemporary Literary Renaissance. New Brunswick: Rutgers P, 1990.

Brent, Linda. "Incidents in the Life of a Slave Girl." The Classic Slave Narratives. Ed. Henry Louis Gates, Jr. New York: Signet Classic, 2002. 437-668.

Butler, Octavia. Bloodchild and other stories. New York: Seven Stories Press, 1996.

_. Interview by Frances M. Beal. In Black Scholar. 17 (March-April 1986): 14- 18.

_. Interview by Joan Fry. In African American Literary Criticism 1773 to 2000. New York: Twayne Publishers, 1999.

_.. Interview by Larry McCaffery. In Across Wounded Galaxies. Urbana and Chicago: University of Illinois Press, 1990, 54-70.

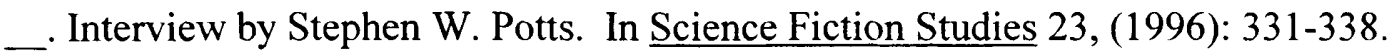

_.Introduction. Bloodchild and other stories. By Butler. New York: Seven Stories Press, 1996.

_. Kindred. Boston: Beacon Press, 1979. 
_. Parable of the Sower. New York: Warner Books Inc., 1993.

_. Parable of the Talents. New York: Warner Books Inc., 1998.

_. Wild Seed. New York: Warner Books Inc., 1980.

_. Xenogenesis. New York: Warner Books Inc., 1989.

Campbell, Jane. Mythic Black Fiction: The Transformation of History. Knoxville: The University of Tennessee Press, 1986.

Cazby, Hazel V. Reconstructing Womanhood: The Emergence of the Afro-American Woman Novelist. New York: Oxford IP, 1987.

Cheng, Anne Anlin. The Melancholy of Race. Oxford: University Press, 2000.

Crossley, Robert. Introduction. Kindred. By Octavia Butler. Boston: Beacon Press, 1998. ix-xxvii.

Doerksen, Teri Ann. "Octavia E. Butler: Parables of Race and Difference." Into Darkness Peering: Race and Color in the Fantastic. Edited by Elisabeth Anne Leonard. Westport, Conn." Greenwood Press, 1997: 21-34.

Douglass, Frederick. "Narrative of the Life of Frederick Douglass." The Classic Slave Narratives. Ed. Henry Louis Gates, Jr. New York: Signet Classic, 2002. 323-436.

Ellis, David. “L.A. Lawless.” Time. 1 June 1992: 26-29.

Foster, Frances Smith. "Octavia Butler's Black Female Future Fiction." Extrapolation, 23 (1982): 37-49.

Gant-Britton, Lisbeth. "Octavia Butler's Parable of the Sower: One Alternative to a Futureless Future." Women of Other Worlds: Excursions through Science Fiction and Feminism. (1999): 280-294.

Gates, Henry Louis Jr. ed. Reading Black, Reading Feminist: A Critical Anthology. New York: Meridian, 1990.

Govan, Sandra Y. "Connections, Links, and Extended Networks: Patterns in Octavia Butler's Science Fiction." Black American Literature Forum 18 (Fall 1984): 82 87. 
Helford, Elyce Rae. “'Would You Really Rather Die Than Bear My Young?': Gender, Race, and Species in Butler's Bloodchild." African American Review. 28 (194): 259-71.

Hurston, Zora Neale. Mules and Men. Philadelphia and London: Lippincott, 1935.

Ivey, Adriane Louise. "Rewriting Christianity: African American Women Writers and the Bible." Diss. University of Oregon, 2000.

Jacobs, Harriet. Incidents in the Life of a Slave Girl. The Classic Slave

Narratives. Ed. Henry Louis Gates, Jr. New York: Signet Classic, 2002. 437-668.

Kubitschek, Missy Dehn. Claiming the Heritage: African-American Women Novelists and History. Jackson and London: University Press of Mississippi, 1991.

McDowell, Deborah E. and Arnold Rampersad. Ed. Slavery and the Literary Imagination. Baltimore and London: The Johns Hopkins University Press, 1989.

Melzer, Patricia. "'All that you touch you change': Utopian Desire and the Concept of Change in Octavia Butler's Parable of the Sower and Parable of the Talents." Femspec, 3, no. 2 (2002): 31-52.

Miller, Jim. "Post-Apocalyptic Hoping: Octavia Butler's Dystopian/Utopian Vision." ScienceFiction Studies, 25, no. 2 (1998): 336-360.

Mitchell, Angelyn. "Not enough of the past: feminist revisions of slavery in Octavia E. Butler's Kindred." MELUS v. 26 Fall 2001: 51-75. FirstSearch. OCLC First Search. FIU Libraries, Miami, FL 28, March 2003 http://www.firstsearch.org/

. The Freedom to Remember: Narrative, Slavery, and Gender in Contemporary Black Women's Fiction. New Brunswick: Rutger's UP, 2002.

Mixon, Veronica. "Futurist Woman: Octavia Butler," Essence. 9 (April 1979), 12, 15.

Morrison, Toni. Beloved. New York: Knopf, 1987.

. "Unspeakable Things Unspoken: The Afro-American Presence in American Literature." Ed. Angelyn Mitchell. Durham and London: Duke University Press, 1994.

Newson, Adele S. "Review of Octavia E. Butler's Dawn and Adulthood Rites." Black American Literature Forum.23 (Summer 1989): 389-96. JSTOR. FIU Libraries, Miami, FL 17, February 2004 http://www.jstor.org/ 
Paulin, Diana R. "De-Essentializing Interracial Representations: Black and White Border Crossings in Spike Lee's Jungle Fever and Octavia Butler's Kindred." Cultural Critique36 (1997): 168-93.

Pollack, Rachel. "Review of Dawn: Xenogenesis 1." Foundation. 44 (1988/9): 68-71.

Prince, Mary. "The History of Mary Prince: A West Indian Slave." The Classic Slave Narratives. Ed. Henry Louis Gates, Jr. New York: Signet Classic, 2002. 249-321.

Pryse, Marjorie and Hortense Spillers. Eds. Conjuring: Black Women, Fiction, and Literary Tradition. Bloomington: Indiana University Press, 1985.

Rampersad, Arnold. "DuBois's The Souls of Black Folk." Ed. Deborah E. McDowell and Arnold Rampersad. Slavery and the Literary Imagination. Baltimore and London: The Johns Hopkins University Press, 1989.

Rushdy, Ashraf H.A. "Families of Orphans: Relation and Disrelation in Octavia Butler's Kindred." College English. 55.2 (1993): 135-57.

Salvaggio, Ruth. "Octavia Butler and the Science Fiction Heroine." Black American Literature Forum, 18 (1994) 78-81. JSTOR. FIU Libraries, Miami, FL 13, January $2004 \mathrm{http}: / /$ www.jstor.org/

Saunders, Charles R. "Why Blacks Should Read (and Write) Science Fiction." Dark Matter: A Century of Speculative Fiction from the African Diaspora. Ed. Sheree R. Thomas. New York: Warner Brooks Inc., 2000.

Shinn, Thelma J. Worlds Within Women: Myth and Mythmaking in Fantasy Literature by Women. Connecticut: Greenwood Press, Inc., 1986.

Thomas, Sheree R. ed. Dark Matter: A Century of Speculative Fiction from the African Diaspora. New York: Warner Books Inc., 2000.

Zaki, Hoda M. "Utopia, Dystopia, and Ideology in the Science Fiction of Octavia Butler." Science Fiction Studies, 17, no. 2 (1990) 239-251. 